\title{
Evaluation of the Low-Energy Design Process and Energy Performance of the Zion National Park Visitor Center
}

Conference Paper NREL/CP-550-39013

October 2005

\section{Preprint}

N. Long, P. Torcellini, S. Pless, and R. Judkoff

To be presented at the 2006 ASHRAE Winter Meeting Chicago, Illinois

January 21-25, 2006
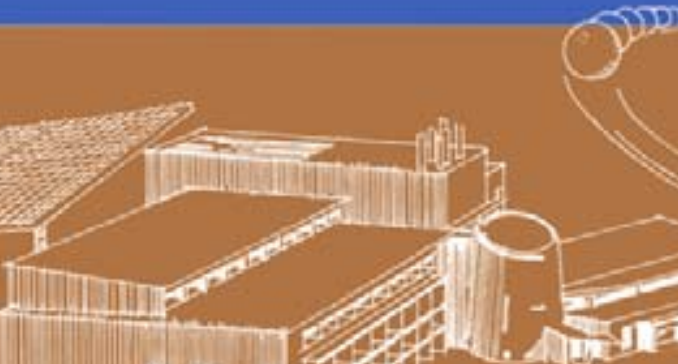


\section{NOTICE}

The submitted manuscript has been offered by an employee of the Midwest Research Institute (MRI), a contractor of the US Government under Contract No. DE-AC36-99G010337. Accordingly, the US Government and MRI retain a nonexclusive royalty-free license to publish or reproduce the published form of this contribution, or allow others to do so, for US Government purposes.

This report was prepared as an account of work sponsored by an agency of the United States government. Neither the United States government nor any agency thereof, nor any of their employees, makes any warranty, express or implied, or assumes any legal liability or responsibility for the accuracy, completeness, or usefulness of any information, apparatus, product, or process disclosed, or represents that its use would not infringe privately owned rights. Reference herein to any specific commercial product, process, or service by trade name, trademark, manufacturer, or otherwise does not necessarily constitute or imply its endorsement, recommendation, or favoring by the United States government or any agency thereof. The views and opinions of authors expressed herein do not necessarily state or reflect those of the United States government or any agency thereof.

Available electronically at http://www.osti.gov/bridge

Available for a processing fee to U.S. Department of Energy and its contractors, in paper, from:

U.S. Department of Energy

Office of Scientific and Technical Information

P.O. Box 62

Oak Ridge, TN 37831-0062

phone: 865.576.8401

fax: 865.576 .5728

email: mailto:reports@adonis.osti.gov

Available for sale to the public, in paper, from:

U.S. Department of Commerce

National Technical Information Service

5285 Port Royal Road

Springfield, VA 22161

phone: 800.553 .6847

fax: 703.605.6900

email: orders@ntis.fedworld.gov

online ordering: http://www.ntis.gov/ordering.htm 


\title{
Evaluation of the Low-Energy Design Process and Energy Performance of the Zion National Park Visitor Center
}

\begin{abstract}
In line with the mission of the National Park Service, its staff and the authors designed the Zion National Park Visitor Center to use 70\% less energy than a comparable visitor center built to Federal Energy Code 10 CFR 435 (DOE 1995). The authors used an integrated design process, including extensive simulations, to minimize the building's energy consumption. The result was a passive solar commercial building that makes good use of the thermal envelope, daylighting, and natural ventilation. Passive downdraft cooltowers provide all the cooling. Two Trombe walls provide a significant amount of heat for the building. After two years of metering, the results show a net energy use intensity of $24.7 \mathrm{kBtu} / \mathrm{ft}^{2}$ and a $67 \%$ energy cost saving. Low energy use and aggressive demand management result in an energy cost intensity of $\$ 0.43 / f t^{2}$. The paper discusses lessons learned related to the design process, the daylighting, the PV system, and the HVAC system.
\end{abstract}

\section{INTRODUCTION}

Zion National Park (ZNP) in southwestern Utah has experienced a substantial increase of visitors over the past two decades. Associated with these large crowds were impacts to resources and visitor experience. To reduce environmental impact and improve visitor experience, National Park Service (NPS) staff planned and developed a new Visitor Center and an alternative transportation system at the Springdale Park entrance. NPS staff wanted their new Visitor Center to complement the natural beauty of ZNP and had a strong design goal of minimizing energy use and environmental impact. Saving and protecting natural resources are core to the mission of the NPS, and energy is considered part of the natural resource. To help achieve its energy goals, the NPS requested technical support from the authors to help integrate energy efficiency into the design process of the new Visitor Center. The collaboration between NPS and the authors lasted throughout the duration of the project from predesign through postoccupancy.

The facility opened in May 2000 and includes an 8,800- $\mathrm{ft}^{2}\left(817-\mathrm{m}^{2}\right)$ Visitor Center (with interpretative displays, offices, and retail space for the Zion Natural History Association) and a 2,756- $\mathrm{ft}^{2}\left(256-\mathrm{m}^{2}\right)$ Comfort Station (restrooms). Although budgetary limits were important, they were considered in the context of a building that had to be constructed in a remote place and be extremely durable to withstand the heavy pedestrian traffic for at least 100 years. These requirements are unique to NPS architecture. Nevertheless, some of the energy design solutions reduced construction costs, as discussed in the Design section of this paper.

The objectives of this research are to evaluate the integrated design process used to design the Zion Visitor Center and to evaluate the whole-building energy performance during normal operation and determine whether the original low-energy design goals were met. This paper is part of a series of six case studies to develop, document, analyze, and evaluate the processes by which highly energy-efficient buildings can be reliably produced. In the Zion project, the authors were able to test a 10-step, low-energy design process (sometimes referred to as an integrated design process) (Torcellini et al. 1999).

This paper provides a background on the integrated design process, a discussion of how the integrated design was applied for the Zion project, and a description of the as-built Visitor Center. Next, postoccupancy evaluation methods are discussed, whole-building energy performance metrics are presented, and the demand controls, lighting, heating systems, and cooling systems are analyzed. Finally, recommendations based on lessons learned from this project are presented along with summarized conclusions.

\section{INTEGRATED DESIGN PROCESS BACKGROUND}

The low-energy design process, or integrated design process, covers predesign through postoccupancy, relies heavily on building energy simulation, includes other important qualitative and quantitative features such as design charrettes with all members of the design team, and establishes energy goals through computer modeling. This process begins with predesign, where the building size, type, location, and use are known. The process then continues through design, construction, and commissioning, assuming a team committed to low-energy building design already has been formed. The integrated design process requires the project team - the architect, systems engineers (lighting, electrical, and mechanical), energy consultants, and the building owner and occupants-to 
commit to work together to meet aggressive energy performance goals. Each member is encouraged to find solutions and offer suggestions that benefit other disciplines, the whole process, and ultimately the building design.

The team's combined efforts to reduce building energy consumption begin at the conceptual design phase and continue through the design development phase. A low-energy building requires the project team to set and commit to a low-energy performance goal. Once the project team is committed to minimize energy use, the integrated design process can be used to provide information for decision making and trade-off analysis. During the construction and commissioning phases, the design team cooperatively ensures that integrated architectural features (e.g., daylighting and managed solar gains) and engineered building systems are built and function as designed. Once the building is occupied, the team supports the building operators as they learn how the building is intended to operate. Finally, the design team is responsible for understanding how the building actually operates over the long term, so this and future buildings can realize energy savings over the years. This low-energy design process is outlined in Table 1.

Table 1. Ten-Step Process for Designing and Constructing Low-Energy Buildings

\begin{tabular}{|c|c|}
\hline Predesign & $\begin{array}{l}\text { 1. Set specific and measurable energy performance goals, which may include percent energy } \\
\text { savings, percent energy cost savings, or emission reductions. The entire team must understand } \\
\text { these goals and how they are affected by design features. Also at this stage, the design team } \\
\text { should develop a thorough understanding of the building site, local weather patterns, and } \\
\text { building functional requirements. At this point, the design team should brainstorm energy } \\
\text { solutions, especially those that affect the architecture. Each building is unique and will have a } \\
\text { different minimization strategy. } \\
\text { 2. Create a base-case building model to quantify base-case energy use and costs. The base-case } \\
\text { building is solar neutral (equal glazing areas on all wall orientations) with equivalent floor area } \\
\text { and meets the requirements of applicable energy efficiency codes such as ASHRAE Standards } \\
\text { 90.1 (ASHRAE 2004). } \\
\text { 3. Complete a parametric analysis of the base-case model to determine sensitivities to specific load } \\
\text { components. Sequentially eliminate loads from the base-case building, such as conductive } \\
\text { losses, lighting loads, solar gains, and plug loads. } \\
\text { Develop preliminary design solutions. The design team brainstorms possible solutions, which } \\
\text { may include strategies to reduce lighting and cooling loads by incorporating daylighting or to } \\
\text { meet heating loads with passive solar heating. }\end{array}$ \\
\hline Schematic Design & $\begin{array}{l}\text { 5. Incorporate preliminary design solutions into a computer model of the proposed building design. } \\
\text { Energy impact and cost effectiveness of each variant are determined by comparing the calculated } \\
\text { energy performance with the original base-case building and to the other variants. Variants with } \\
\text { the most favorable results should be incorporated into the building design. } \\
\text { 6. Prepare preliminary set of construction drawings. These drawings are based on the decisions } \\
\text { made in Step 4. Architectural decisions made during the schematic design can have the greatest } \\
\text { impact on the long-term building energy performance. }\end{array}$ \\
\hline $\begin{array}{l}\text { Design } \\
\text { Development }\end{array}$ & $\begin{array}{l}\text { 7. Identify the HVAC system that will meet the predicted loads. The HVAC system should } \\
\text { complement the building architecture and exploit the specific climactic characteristics of the site } \\
\text { for maximum efficiency. Often, the HVAC system capacity is much less than in a typical } \\
\text { building. Verify that simulations are updated with design changes. }\end{array}$ \\
\hline $\begin{array}{l}\text { Construction } \\
\text { Documents and } \\
\text { Bid }\end{array}$ & $\begin{array}{l}\text { 8. Finalize plans and specifications. Ensure that the building plans are properly detailed and that } \\
\text { the specifications are accurate. The final design simulation should incorporate all cost-effective } \\
\text { features. Savings that exceed } 50 \% \text { from a base-case building are frequently possible with this } \\
\text { approach. }\end{array}$ \\
\hline Construction & $\begin{array}{l}\text { 9. Rerun simulations before design changes are made during construction. Verify that changes will } \\
\text { not adversely affect the building's energy performance. }\end{array}$ \\
\hline $\begin{array}{l}\text { Postoccupancy } \\
\text { Evaluation }\end{array}$ & $\begin{array}{l}\text { 10. Commission all equipment and controls. Educate building operators. Only a properly operated } \\
\text { building will meet the original energy efficiency design goals. Building operators must } \\
\text { understand how to properly operate the building to maximize its performance. Measure and } \\
\text { evaluate actual energy performance to verify design goals were met. }\end{array}$ \\
\hline
\end{tabular}

\section{ZION DESIGN PROCESS}

\section{Predesign}

Part of the success of the Zion project was a commitment to climate-sensitive design that started in the predesign stage. The initial predesign activities included a set of on-site charrettes that allowed the design team to become familiar with the unique terrain and climate features. ZNP staff, the authors, and NPS engineers and 
architects participated. The local microclimate provided many ideas for design concepts that could be used to provide comfort in and around the Visitor Center. The Virgin River canyon controls many aspects of the microclimate. The narrow canyon walls, splashing water, and vegetation at the riverbanks provide shade and evaporatively cooled air in sharp relief to the aridity and extreme heat. In some places, seeps wet the canyon walls to create a cooling effect. In other places, the seeps nourish blooms of wet moss that behave much as the wetted media in a commercial evaporative cooler. The overall geometry of the canyon, which is deep and narrow upriver of the site and widens progressively downriver, creates a diurnal chimney effect with upcanyon winds from about noon to midnight and downcanyon winds from midnight to noon. The lighting in the narrow parts of the canyon is diffuse with a pleasant contrast ratio and without direct sunlight. During the winter, the solar heating of exposed canyon mass surfaces often provides adequate outside comfort during the day.

A temporary weather station recorded hourly integrated values of shielded air temperature, relative humidity, global horizontal solar radiation, wind speed, and wind direction. We used these data to quantify the observations of the design team. These were important observations for a region where the daily high summer temperatures regularly exceed $100^{\circ} \mathrm{F}\left(38^{\circ} \mathrm{C}\right)$. The typical weather for $\mathrm{ZNP}$ is cooler than the surrounding towns. The number of heating degree-days based on $65^{\circ} \mathrm{F}\left(18^{\circ} \mathrm{C}\right)$ averages $3,435^{\circ} \mathrm{F}$ and the number of cooling degree-days based on $75^{\circ} \mathrm{F}$ $\left(24^{\circ} \mathrm{C}\right)$ averages $961^{\circ} \mathrm{F}$.

Thus, the observation of Zion's natural environment is where many of the overall energy, lighting, and human comfort architectural design concepts for the complex originated. These are summarized as follows:

- Create a shaded microclimate around the buildings in summer and solar exposure in winter with plantings of deciduous trees and overhead arbors.

- Provide irrigation throughout the space with small canals similar to the historic ones in the canyon. Although not implemented in this project, porous patio materials can be used to create an evaporatively cooled walking surface.

- Create passive evaporative downdraft cooltowers to cool the building without blowers or vapor compression equipment.

- Use the diurnal winds to help drive a natural ventilation system and boost the cooltower's air delivery with wind pressure.

- Control automated clerestory windows and the cooltowers with the building automation system to create an integrated, controllable natural cooling system.

- Specify the thermal and optical properties of the glass; size and orient windows and shading devices to provide diffuse light with minimal solar load in summer.

- Use massive building materials on the interior to modulate temperature swings and store solar heat in winter and cool night air in summer.

- Construct noncirculating Trombe walls on the south faces of the buildings for additional passive heating with a time delay into the late afternoon and evening hours.

- Allow enough south-oriented pitched roof surface to accommodate photovoltaic (PV) panels so the building can operate effectively and comfortably during frequent summer power outages.

In addition to borrowing elements from the natural cooling and heating, the design team evaluated the original program requirements for building size to determine whether further energy-saving measures could be incorporated into the design. Because $90 \%$ of the annual visitors are in ZNP during the hot and dry summer, the design team determined that many exhibits could be moved to permanent areas outside the building. By providing shading and water for visitors and creating outdoor exhibit areas, the building became smaller, less expensive, and would require less energy to operate. Finally, visitors would have access to the displays when the Visitor Center is closed. Overall, the design team reduced the building footprint from $18,000 \mathrm{ft}^{2}\left(1,670 \mathrm{~m}^{2}\right)$ to $11,726 \mathrm{ft}^{2}\left(1090 \mathrm{~m}^{2}\right)$.

Ideally, at this point of the predesign process, energy simulations would have been used to determine the minimum energy targets for the buildings, incorporating the climate and the program goals. In this case, predesign simulations were not completed at this stage. However, the team wanted an aggressive energy cost savings goal, so a $70 \%$ goal was selected. Establishing this goal was critical to getting the entire team on the same page and for the team to realize that energy cost savings were important to the project and should help to drive the design decisions, starting with the architecture of the building. It was also critical in making the envelope of the building the first line of defense in creating a low-energy building. The form of the building followed the needs of the occupants and the climate of the site. 


\section{Schematic Design}

During the schematic design process, the authors used DOE-2 simulations to quantitatively evaluate the effectiveness of the strategies for reducing loads and using natural heat flows in the canyon. DOE-2 is a wholebuilding simulation program that we used to calculate hourly building heating and cooling loads, simulate the operation of primary and secondary HVAC systems, calculate lighting and equipment energy use, and perform a utility cost analysis (Winkelmann et al. 1993). We first carefully studied the energy-saving strategies that affected building architecture to prepare for the next design process step; we then incorporated energy-efficient strategies into the architectural design. For example, the original building envelope concept included tall architectural elements to unify the building with the surrounding canyon walls. The design team evaluated the downdraft cooltowers, which are similar to direct evaporative coolers but without fans, as one means of introducing a tall element into the architectural scheme. Original plans called for five cooltowers at the building corners. This design met the architectural needs of the building and provided energy performance benefits. The building was further cooled with strategically placed operable windows that promote natural ventilation and passively move cool air through the space.

We carefully designed shading devices to minimize the solar gains so all cooling and ventilation loads could be met with natural ventilation and the cooltowers. The only mechanical input to the cooling system is a pump that circulates water through the evaporative media. During the winter, ventilation requirements are lower because of fewer visitors and can be met by infiltration through the building envelope as well as people entering and leaving the building. Trombe walls were designed to provide most of the building heating. As with the cooling system design, simulations were used to optimize the envelope for winter performance.

At this point in the process, the design team investigated the potential impact of incorporating a PV system into the roof for electrical power, and provided the option to use a grid-tied PV system in the future by designing a southfacing roof that was sloped to maximize electricity production. In addition, we added a conduit to the roof and mounting brackets to the base building plan. NPS personnel were concerned about the poor power reliability at the park. A UPS (uninterruptible power supply) was included in the original plan for the electrical system. By specifying an inverter that could handle the direct-current input from a PV system, the UPS could be PV powered. The UPS batteries were designed to deliver 2 hours of power without any PV. Using $3.6 \mathrm{~kW}$ of PV allowed the system to operate as long as there is sunlight. Space for an additional $3.6 \mathrm{~kW}$ of PV was allocated on the roof. We designed this system to be directly grid-tied.

Overall, observations from the predesign process helped clarify the role of the natural environment in which the building would be located and prompted a careful analysis of the programmatic needs of the building. Daylighting, natural ventilation, evaporative cooling, building shape and envelope features that minimize summer solar gains, massive building materials to stabilize indoor temperatures, passive solar heating, and siting with relation to mature trees and newly constructed outdoor shade structures all contribute to the integrated building design. A roofmounted PV array further reduces the building's environmental impact.

The conceptual design for the ZNP Visitor Center is an example of how architectural features can enhance energy performance and provide a unique aesthetic style. The building's window overhangs, clerestories, roofline, massive construction materials, and other architectural features all improve energy performance. Computer simulations allowed engineers to create an envelope that functions as most of the HVAC system.

\section{Design Development}

The building layout changed partway through the design development process step. The offices and break room were moved to the south side of the building. The number of cooltowers was reduced to three, including one for the Comfort Station, because the building engineer concluded they would provide enough airflow. For architectural reasons, the amount of north and west glass was increased, although the tree canopy and building shading keep these surfaces shaded most of the summer. Finally, the outdoor cooltower was removed, so the two cooltowers were expected to condition inside and outside spaces. A study indicated that the cost of propane in Springdale would exceed that of electric resistance heating. This prompted conversion of the building to an all-electric one, which eliminated the fuel storage. However, this determination is contingent upon restricting resistance heating to only those periods when additional demand charges are not imposed. Electric radiant panels were installed in the ceiling on 12 zones to complement heat obtained from the Trombe walls. The cost of zoning the spaces was minimal and provided for flexibility in controlling building demand. The result was an HVAC system that requires no ductwork or mechanical spaces, which saves money and allows for uncluttered ceiling spaces. Transfer fans (from the offices to the main space) were installed to pull air from the main space to the offices. Transfer grilles were installed between the break room and the main space to cool the break room and offices. After the building operated for a year, fans were added to augment the natural ventilation. 
The building redesign was not resimulated as instructed in the 10-step low-energy design process. This resulted in some performance issues, which will be discussed later. The design team carefully reviewed all drawings and documents to minimize any errors and misinterpretation of the design during construction.

\section{ZION NATIONAL PARK VISITOR CENTER DESCRIPTION}

The as-built Visitor Center includes the $8,800-\mathrm{ft}^{2}\left(817-\mathrm{m}^{2}\right)$ building (floor plan in Figure 1) and a 2,756- $\mathrm{ft}^{2}$ $\left(256-\mathrm{m}^{2}\right)$ restroom facility called the Comfort Station next to the main building. The Comfort Station includes many features found in the main building, including a cooltower, a separate building automation system (BAS), and daylighting.

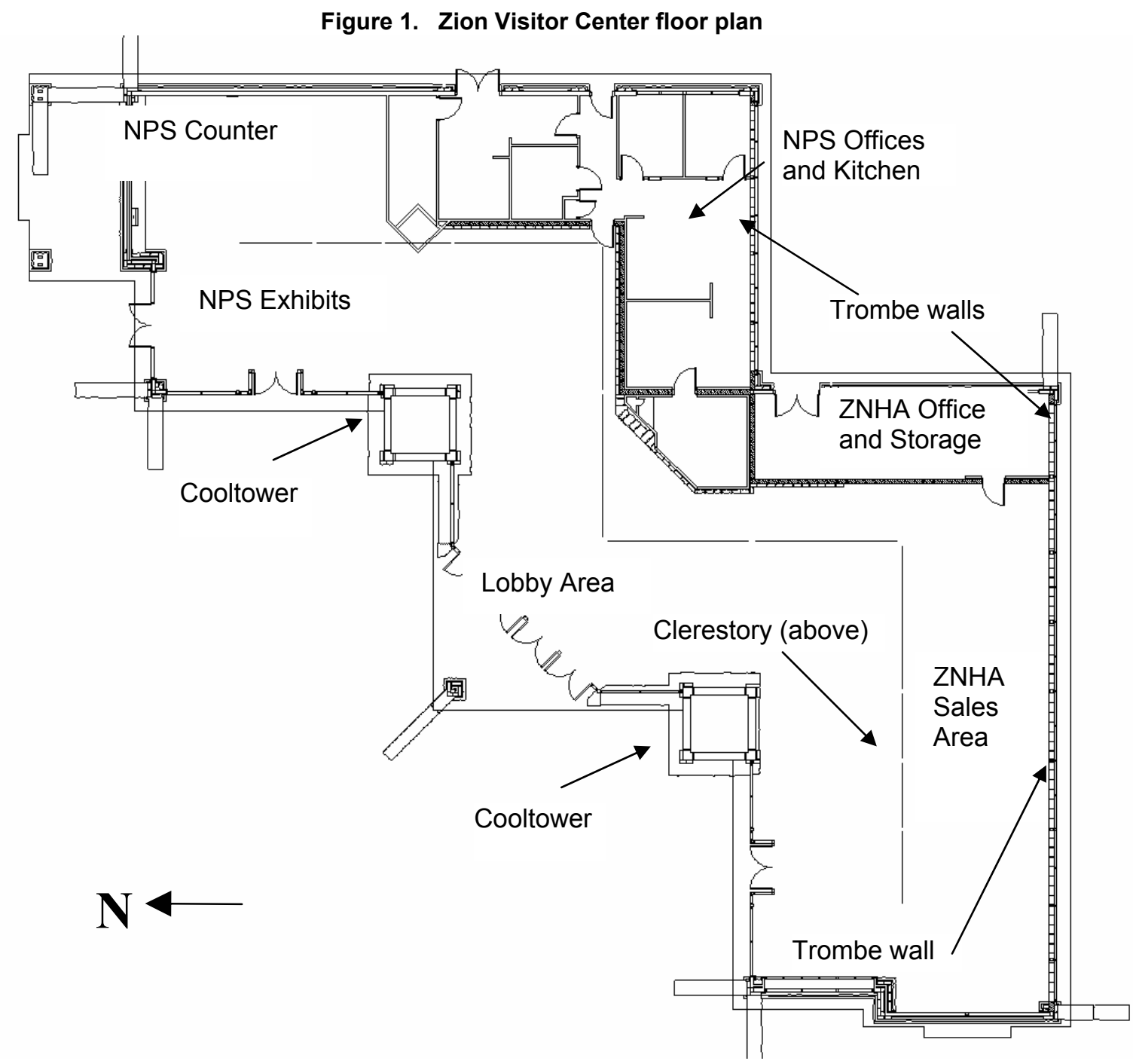

An illustration of the ZNP Visitor Center and some of the energy-efficient features is shown in Figure 2. The Visitor Center and Comfort Station have well-insulated building envelopes to minimize heating and cooling loads. To minimize heating loads, the buildings were designed with Trombe walls and concrete floors to provide high thermal mass. We designed the clerestory to provide daylighting and reduce electric loads. These windows also provide direct winter solar gain and are protected from the summer sun with overhangs. Glass on the north and west facades use a suspended film to achieve very low solar heat gain coefficients and low U-values. The main entrances to both buildings are to the northwest as most of the visitation is in the summer. This orientation allowed landscaping to help minimize the summer sun and increase visitor comfort. 
Figure 2. As-built Zion layout and energy-efficient features

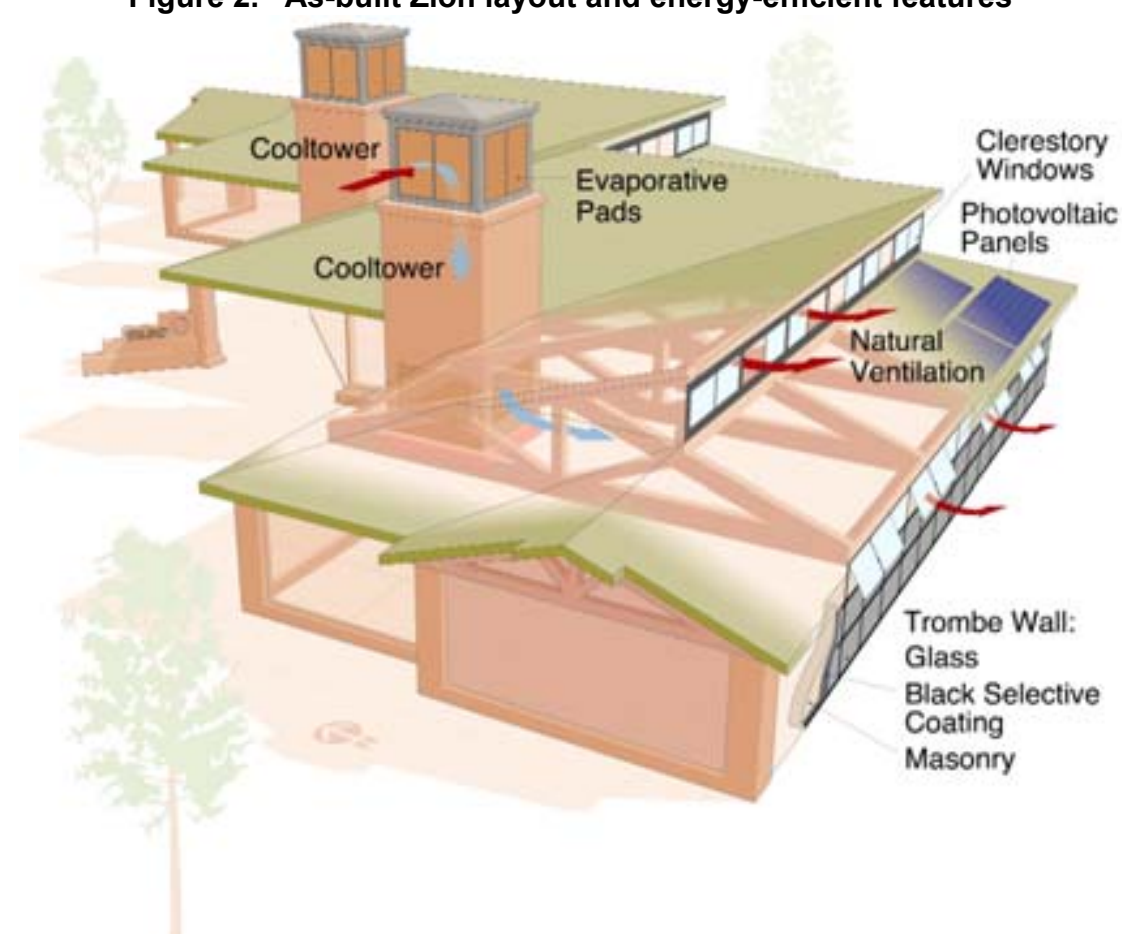

A key part of the design process was to use computer simulation to minimize heating, cooling, and lighting loads with the envelope of the building. A heating and cooling system was designed to match the loads for the space. Some cooling is done with natural ventilation via the operable clerestory windows. Additional cooling is provided with passive downdraft evaporative cooltowers. The cooltowers are enabled when natural ventilation is inadequate. The cooltowers were designed to operate on natural convection that is driven primarily by buoyancy forces. Water is pumped to four sets of pads on the top of the tower. The water evaporates into air that passes through the pads to provide cool air. This cool, dense air "falls" through the tower and enters the building through the large openings at the bottoms of the towers. The cool air drawn into the building by the cooltowers causes the hot air already inside the space to rise and exit the building through the open clerestory windows. Neither tower has fans. The only energy required for each tower is a $1 / 3-\mathrm{hp}(249-\mathrm{W})$ water pump.

The building is heated by combining passive solar gains through windows, Trombe walls, and a series of electric radiant panels. Solar radiation is absorbed and stored in the masonry wall. The collected heat is then released back into the building when the temperature drops later in the day. The exterior sheet of high-transmittance glass and a black selective coating maximize the solar absorptivity and minimize heat loss. The Trombe walls constitute more than $40 \%$ of the south-facing walls. The interior warm surface provides radiant comfort. The temperature of the inside surfaces of the Trombe walls can exceed $100^{\circ} \mathrm{F}\left(37.8^{\circ} \mathrm{C}\right)$ in the winter. Electrical radiant ceiling panels provide supplemental heat when cloudy conditions prevent adequate heat output from the Trombe walls.

Electrical loads are controlled by a BAS that maintains the energy-efficient lighting system as well as the heating and cooling systems. The BAS also monitors energy consumption and environmental variables for demand limiting and data analysis. One BAS was installed in the Visitor Center, and one in the Comfort Station.

The primary source of light in the Visitor Center is daylight entering through clerestory windows and a strip of windows high on the walls. Electric lighting was installed to provide additional light when needed. T-8 lights were installed above displays. Most of the Visitor Center fixtures are $88 \%$ indirect with $11 \%$ direct. Fluorescent fixtures were used on most exterior walls. The offices, back hall, break area, storeroom, and restroom in the Visitor Center use fluorescent fixtures connected to motion sensor controls. The lighting power density (LPD) in the offices is 1.0 $\mathrm{W} / \mathrm{ft}^{2}\left(11 \mathrm{~W} / \mathrm{m}^{2}\right)$ and $0.9 \mathrm{~W} / \mathrm{ft}^{2}\left(9.7 \mathrm{~W} / \mathrm{m}^{2}\right)$ in the bookstore and display areas. Twenty-four lighting zones allow for different light levels with stepped daylighting controls. Each zone has a minimum illuminance threshold and a time delay to prevent excessive cycling. In addition, the BAS controls high-intensity discharge spotlights that highlight the Trombe walls, wall displays, and the cooltowers. The entryway of the building also uses these fixtures. The Comfort Station uses fluorescent fixtures with T-8 lamps. The entire Comfort Station is split into seven zones of lights, controlled with the BAS based on occupancy and available daylighting. 
A 7.2-kW roof-mounted PV system uses a UPS circuit to offset building electrical loads and ensure a power supply during the frequent utility grid outages. Excess power produced by the PV system is fed into the utility grid. The Visitor Center has a net-metering agreement with the local utility so that it receives credit from the utility for excess power produced by the system. This agreement was the first net-metering agreement to be placed in Utah. The UPS system contains 200 Ah of battery capacity, enough to run the UPS for several hours without solar insolation. The UPS provides power to the computer equipment, cash registers, window actuators, cooltower pumps, telephone switch, and BAS. During power outages, the computer equipment, cash registers, and telephone switch are required to continue business functions; the window actuators and cooltower pumps ensure the building cooling system continues to operate. The daylighting system provides enough light during most typical business hours.

The total cost to construct the Visitor Center was less than the original program planned building. Integrating energy features into the envelope increased total envelope cost; however, reducing infrastructure and mechanical systems (including elimination of the mechanical room) reduced costs.

\section{EVALUATION PROCEDURES}

The authors collaborated with NPS staff to evaluate the Visitor Center from a whole-building perspective, which looks at how building systems affect the energy performance of a building as a whole, rather than how individual systems perform. The evaluation measured building performance during typical operation (Step 10 in the low-energy design process), which included assessing the Visitor Center and Comfort Station measured energy performance from September 1, 2000 to June 1, 2003. The building evaluation methodology used a conventional building model with measured weather data to calculate energy performance savings from November 2001 through October 2002. Performance indicators analyzed included site energy savings, source energy savings, and site cost energy savings. This evaluation was crucial to achieve and verify the low-energy design goals.

The building did not have a commissioning phase, either by an independent commissioning agent or by the construction management staff. It was, however, in many ways commissioned as instrumentation was installed and verified. In many respects, this is part of the continuous commissioning process - examining actual data over a long period to continually refine the building operation. The staff at ZNP is committed to maintaining the building. A complete building energy dataset has been collected since November 2001. The experience gained from monitoring this building indicates that a dedicated monitoring system should be used independently of the BAS. BAS systems are often designed to collect information and provide control—not store information for future use.

\section{Building Energy Monitoring Methods}

We measured the energy use of the building during typical operation to complete Step 10 of the energy design process. The team measured energy use at a variety of end-use locations and at building energy supply connections from the PV system and the utility company. The building's BAS measured and recorded energy flows every 15 minutes from September 1, 2000 through June 1, 2003.

The Visitor Center monitoring equipment includes watt-hour transducers that measure electricity flows to specific end uses and is recorded with the BAS. End uses are grouped into HVAC, lighting, and equipment loads. We also monitored local environmental conditions. Weather variables monitored included outdoor dry-bulb temperature, relative humidity, wind speed and direction, and horizontal and vertical irradiance. A calculation of an energy balance around the utility meter was made possible by directly measuring the primary end uses in the building. This energy balance accounted for electricity flowing into the building and provided an opportunity to verify metering reliability.

We configured the monitoring system to allow for redundancy, and then compared the energy consumption from the main utility meter to the sum of all the end-use meters. After some initial system review and upgrade, the energy balance of the installed meters compared very closely to the installed utility meter, as shown by the comparison of the utility meter to the sum of the end use meters in Figure 3. This figure is an X-Y plot of the Visitor Center hourly utility meter versus the hourly sum of the end-use meters from November 2001 to February 2003. The comparison of the two meters yielded a $1.4 \%$ error, with a linear correlation of nearly one. The utility meters at Zion are rated to be accurate to $0.5 \%$ of full-scale. Assuming the meters have the same scale, the total error possible of the data is $1.51 \%$. We considered this error reasonable and the data were considered reliable. 
Figure 3. Verification of utility and measured data, November 2001 to February 2003

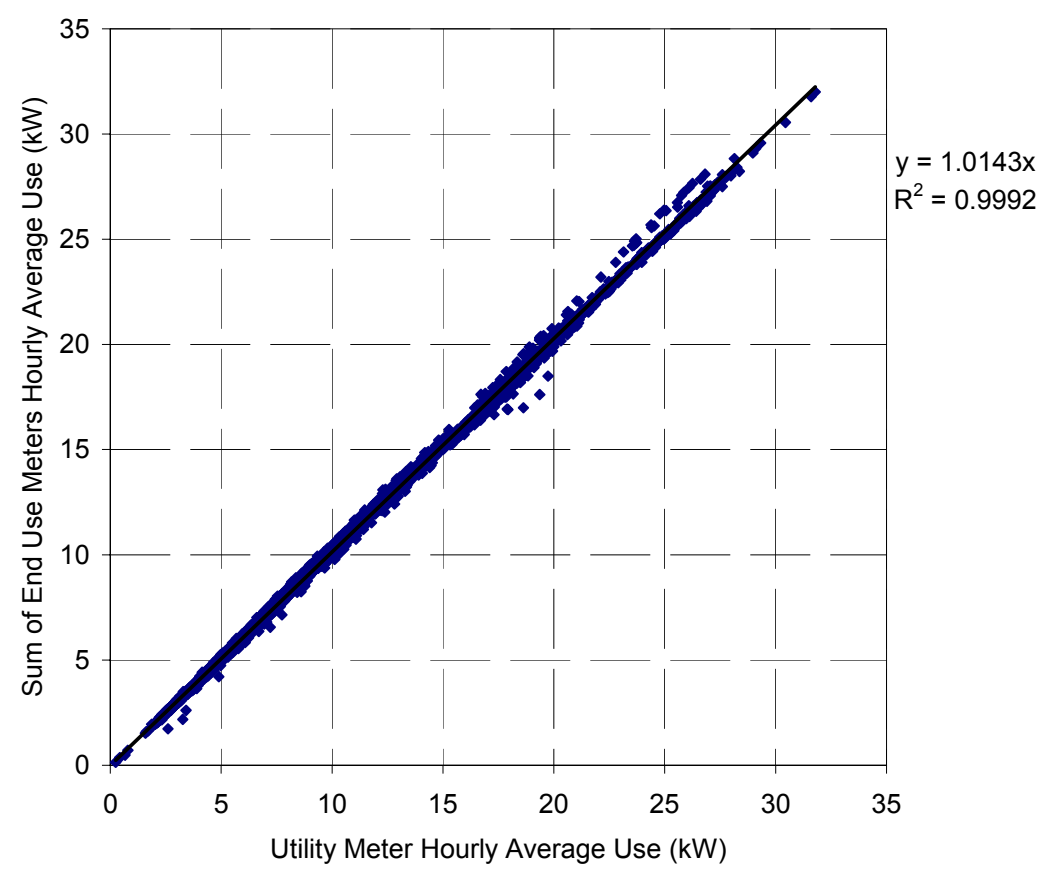

\section{Base-Case Simulation Method}

The whole-building evaluation also includes simulating conventional buildings with DOE-2 to calculate energy savings for typical weather years. A conventional building, or base case, was modeled to provide an energy benchmark. The base case was simulated with measured weather data, and then compared to measured site use, source use, and utility bills. Performance indicators analyzed include site energy savings, source energy savings, and site cost energy savings. The flow chart in

Figure 4 shows how the measured data were used in the model and the process used to obtain the percent savings results.

Figure 4. Whole-building evaluation flowchart: as-built building and base-case model

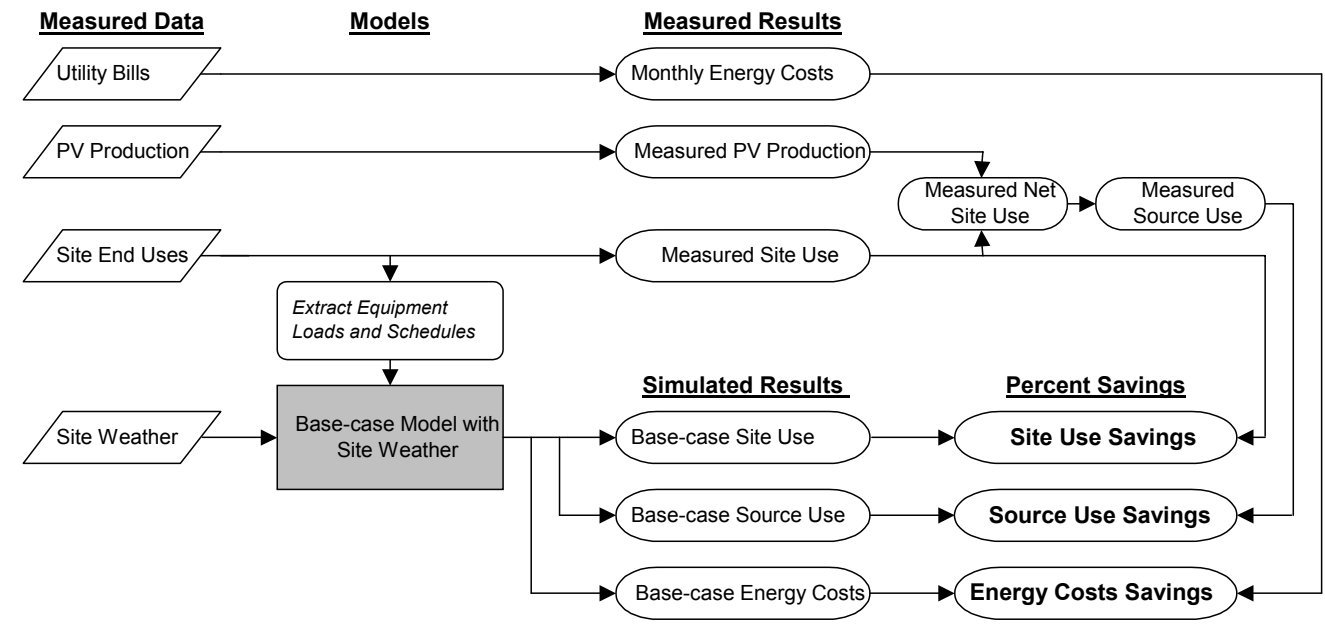

The base case was modeled as a square, single-floor building. The model was solar neutral (equal glazing areas on all orientations) and met the minimum requirements of the Federal Energy Code 10 CFR 435 (DOE 1995) (based on ANSI/ASHRAE/IESNA Standard 90.1-1989 (ASHRAE 1989) with more stringent lighting requirements). 
Based on visitor data from the NPS, we assumed the maximum number of occupants to be 100 , and occupancy schedules were based on typical operation hours of the Visitor Center. Outside ventilation air in the base-case model was set at a constant rate during occupied hours equal to $15 \mathrm{cfm}(7.1 \mathrm{~L} / \mathrm{s})$ per person. We modeled base-case heating and cooling set points based on the actual set points. The LPDs were modeled as $2.2 \mathrm{~W} / \mathrm{ft}^{2}\left(24 \mathrm{~W} / \mathrm{m}^{2}\right)$ in the retail and display zones $(16.1 \mathrm{~kW}$ total $), 1.4 \mathrm{~W} / \mathrm{ft}^{2}\left(15 \mathrm{~W} / \mathrm{m}^{2}\right)$ in the office zones $(2.2 \mathrm{~kW}$ total $)$, and $1.0 \mathrm{~W} / \mathrm{ft}^{2}(11$ $\left.\mathrm{W} / \mathrm{m}^{2}\right)$ for the restroom zones $(2.7 \mathrm{~kW}$ total). The lights are assumed to be on during occupied hours, as no daylighting or occupancy sensors are included in the base case. We modeled occupied hours based on the occupancy schedule of 6:00 a.m. to 7:00 p.m. in the summer and 6:00 a.m. to 5:00 p.m. in the winter. Table 2 summarizes building characteristics used in the base-case model.

Table 2. Base-Case Model and As-Built Visitor Center Characteristics

\begin{tabular}{|c|c|c|}
\hline Item & Base-Case Model & As-Built Building \\
\hline Size $-\mathrm{ft}^{2}\left(m^{2}\right)$ & $11,726(1089.4)$ & $11,726(1089.4)$ \\
\hline Heating System & Electric Heat Pump & $\begin{array}{l}\text { Electric Radiant Panels and Trombe } \\
\text { Walls }\end{array}$ \\
\hline Wall R-Value $-\mathrm{ft}^{2} \cdot{ }^{\circ} \mathrm{F} \cdot \mathrm{hr} / \mathrm{Btu}\left(m^{2} \cdot K / W\right)$ & $13.9(2.45)$ & $\begin{array}{l}2.3(0.40) \text { (Trombe Walls) } \\
16.5(2.91) \text { (Standard Wall) }\end{array}$ \\
\hline Window R-Value $-\mathrm{ft}^{2} \cdot{ }^{\circ} \mathrm{F} \cdot \mathrm{hr} / \mathrm{Btu}\left(\mathrm{m}^{2} \cdot \mathrm{K} / \mathrm{W}\right)$ & $1.73(0.30)$ & $\begin{array}{ll}2.3 & (0.41) \text { (South and East) } \\
3.85 \text { (0.678) (North and West) }\end{array}$ \\
\hline Window-to-Wall Area & $28 \%$ All Orientations & $\begin{array}{l}47 \% \text { North, } 16 \% \text { East, } \\
25 \% \text { South, } 26 \% \text { West } \\
\end{array}$ \\
\hline $\begin{array}{l}\text { Floor Perimeter Insulation (48 in Vertical } \\
\text { Foundation Insulation) R-Value }-\mathrm{ft}^{2} \cdot{ }^{\circ} \mathrm{F} \cdot \mathrm{hr} / \mathrm{Btu} \\
\left(m^{2} \cdot \mathrm{K} / W\right)\end{array}$ & $4(0.7)$ & $11.3(1.99)$ \\
\hline Roof R-Value - $\mathrm{ft}^{2} \cdot{ }^{\circ} \mathrm{F} \cdot \mathrm{hr} / \mathrm{Btu}\left(\mathrm{m}^{2} \cdot \mathrm{K} / \mathrm{W}\right)$ & $22.7(4.00)$ & $30.9(5.44)$ \\
\hline Infiltration $(\mathrm{ACH})$ & 0.3 & Unknown (Not Measured) \\
\hline Equipment Load - W/ft ${ }^{2}\left(\mathrm{~W} / \mathrm{m}^{2}\right)$ & $0.75(0.13)$ & $0.75(0.13)$ \\
\hline Daylighting & No & $\begin{array}{l}\text { Yes, Clerestories; Photo Sensors } \\
\text { Controls }\end{array}$ \\
\hline Overhangs & No & Yes \\
\hline Demand Limiting Controls & No & Yes \\
\hline \multicolumn{3}{|l|}{ Lighting Levels $\mathrm{W} / \mathrm{ft}^{2}\left(\mathrm{~W} / \mathrm{m}^{2}\right)$} \\
\hline Office Space & $1.4(15)$ & $0.96(10)$ \\
\hline Retail and Display Space & $2.2(24)$ & $0.90(9.7)$ \\
\hline Restrooms & $1.0(11)$ & $1.0 \quad(11)$ \\
\hline Outdoor and Parking Lot (W) & 400 & 400 \\
\hline
\end{tabular}

The heating and cooling equipment modeled in the base-case model represent typical HVAC equipment with a rated efficiency that complies with the applicable Federal Energy Code. We modeled the heating system as an airsource heat pump with a coefficient of performance (COP) of 2.0 and supplemental electric resistive heat. The cooling system was modeled as a packaged single-zone air conditioner with a COP of 3.0. Many of these base-case characteristics were based on typical park practice information provided by NPS staff. We applied the actual utility rate structure to the base-case model to calculate energy costs. The modeled utility rate structure included a consumption charge of $\$ 0.0277 / \mathrm{kWh}$, a monthly demand charge of $\$ 8.10 / \mathrm{kW}$, a $\$ 15.00$ fixed monthly charge, and a small variable rate adjustment charge. Natural gas is not available at the site.

Ideally, the base-case site energy use, source energy use, and energy costs would be compared to an as-built model to calculate savings for a typical weather year. In this case, an as-built integrated whole-building model of the Zion Visitor Center and Comfort Station was not possible because of limitations in the simulation tools existing at the time. Simulations were used to help design the Visitor Center, but the design models were not integrated to allow for an accurate prediction of as-built, whole-building performance. These limitations include the lack of building-integrated modeling techniques for the energy use and cooling capacity of cooltowers, difficulties modeling the as-built operation of subhourly demand limiting controls with integrated PV production, and uncertainties with Trombe wall thermal models. We attempted to account for the inherent uncertainty involved in comparing measured data to a simulation by calibrating the base-case model with measured weather data, measured equipment loads, and operation schedules. We calibrated the base-case model with measured weather data from November 2001 through October 2002. This modeling procedure accounted for the actual weather conditions in the prediction 
of base-case performance, allowing for a better comparison of the measured energy performance over this simulation period. Actual equipment loads and operation schedules were extracted from the measured data and modeled in the calibrated base-case as well.

\section{MEASURED PERFORMANCE AND EVALUATION}

\section{Measured Whole-Building Performance}

The measured energy consumption and production from November 2001 through May 2003 is shown Figure 5. From November 2001 through October 2002, the annual energy use of the Visitor Center was $92,876 \mathrm{kWh}$, at a site energy intensity of $27.0 \mathrm{kBtu} / \mathrm{ft}^{2} \cdot \mathrm{yr}\left(306 \mathrm{MJ} / \mathrm{m}^{2} \cdot \mathrm{yr}\right)$. The PV system produced $7,860 \mathrm{kWh}$ and met $8.5 \%$ of the total site load. PV production reduced the net site consumption intensity to $24.7 \mathrm{kBtu} / \mathrm{ft}^{2} \cdot \mathrm{yr}\left(281 \mathrm{MJ} / \mathrm{m}^{2} \cdot \mathrm{yr}\right)$. From June 2002 through May 2003, the site energy intensity was $23.8 \mathrm{kBtu} / \mathrm{ft}^{2} \cdot \mathrm{yr}\left(270 \mathrm{MJ} / \mathrm{m}^{2} \cdot \mathrm{yr}\right) ; \mathrm{PV}$ production met $9 \%$ of the total building energy requirements. The net energy use from June 2002 through May 2003 was $21.6 \mathrm{kBtu} / \mathrm{ft}^{2} \cdot \mathrm{yr}$ $\left(245 \mathrm{MJ} / \mathrm{m}^{2} \cdot \mathrm{yr}\right)$. The measured site energy use intensity is significantly better than the ENERGY STAR ${ }^{\circledR}$ or top Commercial Buildings Energy Consumption Survey for buildings (Hicks 2000).

Figure 6 shows the energy consumption distribution by end use from November 2001 through October 2002. The minimal energy consumption of the Comfort Station results in only $15 \%$ of the total site energy consumption, at an energy intensity of $17.4 \mathrm{kBtu} / \mathrm{ft}^{2} \cdot \mathrm{yr}\left(198 \mathrm{MJ} / \mathrm{m}^{2} \cdot \mathrm{yr}\right)$. The Visitor Center heating is the largest single energy end use; Visitor Center plug loads and BAS controlled lighting were the next most energy-intensive loads.

Figure 5. End use daily average monthly consumption, November 2001 through May 2003

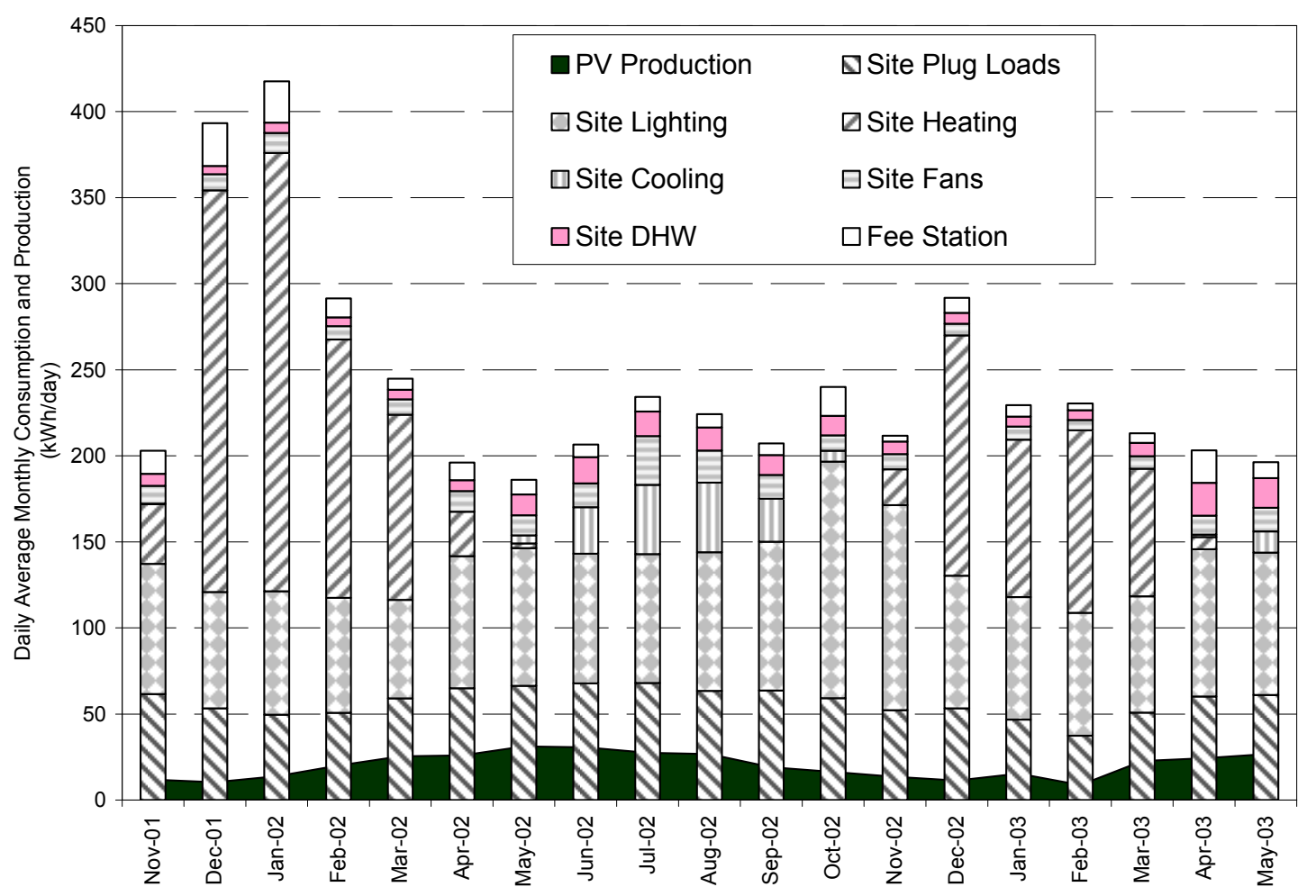


Figure 6. Energy consumption by end use, November 2001 through October 2002

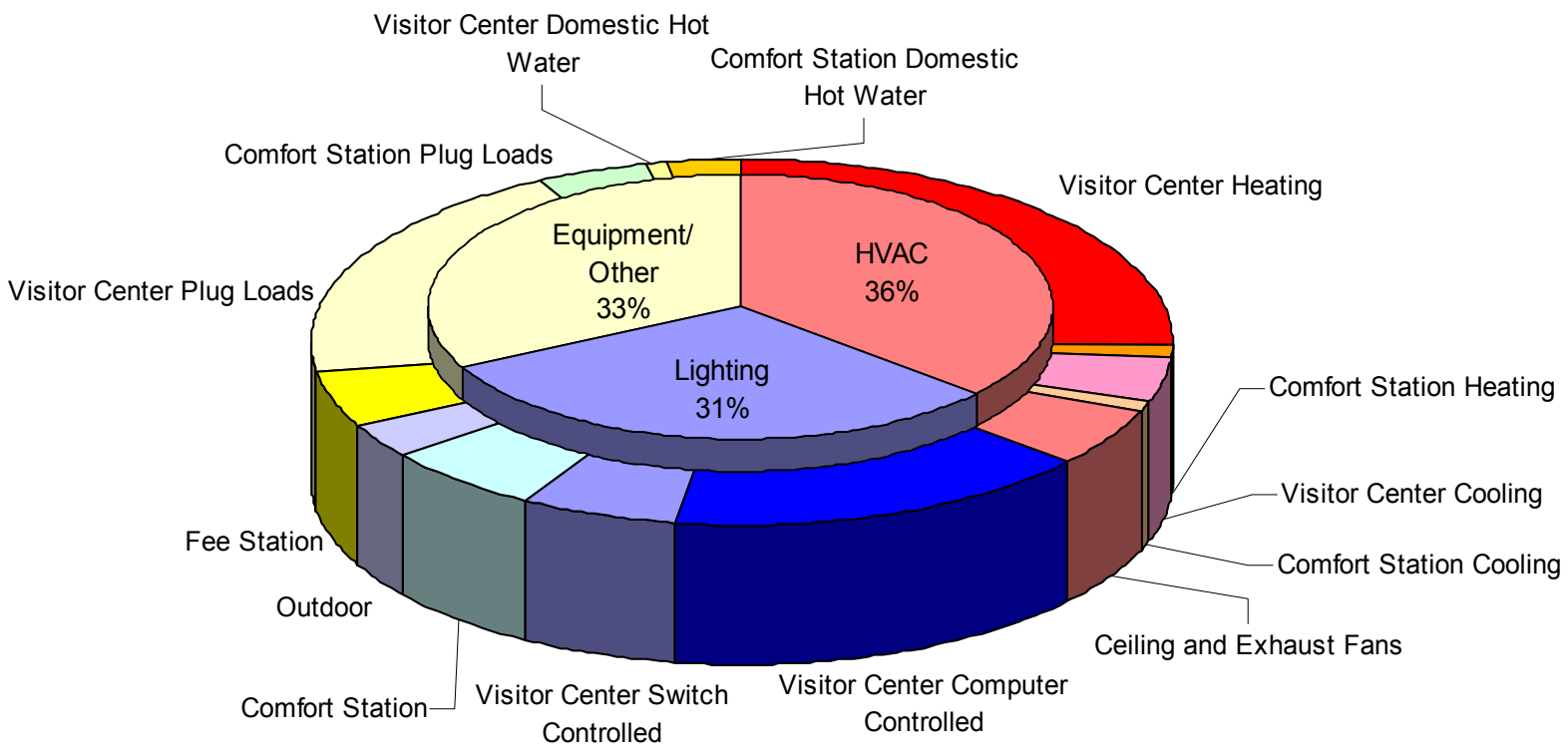

\section{Whole-Building Energy Cost Performance}

The Visitor Center was designed to minimize purchased energy costs; therefore, this is the primary energy performance metric considered. The monthly energy costs are shown in Table 3 . The total monthly energy costs were obtained from the monthly utility bills. Monthly data in Table 3 are represented by the month in which most of the data are contained. (The monthly utility billing cycle did not start on the first of the month and end on the last of the month.) Included in the monthly energy costs are demand charges based on the monthly peak consumption over a 15-minute interval, a consumption charge based on the total electricity consumed over the month, and taxes and fixed charges. The utility rate structure, based on electrical utility bills from Utah Power, includes an energy charge of $\$ 0.0277 / \mathrm{kWh}$, a demand charge of $\$ 8.1 / \mathrm{kW}$, and a $\$ 15.00$ fixed charge with a variable rate adjustment charge. From June 2002 through May 2003, the annual utility costs were $\$ 4,383$ or $\$ 0.37 / \mathrm{ft}^{2}\left(\$ 3.98 / \mathrm{m}^{2}\right)$ based on $11,726 \mathrm{ft}^{2}$ $\left(1089.4 \mathrm{~m}^{2}\right)$ of gross floor area. The energy cost intensity from November 2001 through October 2002 was $\$ 0.43 / \mathrm{ft}^{2}$ $\left(\$ 4.63 / \mathrm{m}^{2}\right)$. 
Table 3. Visitor Center Energy Costs, November 2001 through May 2003

\begin{tabular}{|c|c|c|c|c|c|c|}
\hline & $\begin{array}{c}\text { Demand } \\
\text { Cost } \\
\end{array}$ & $\begin{array}{c}\text { Consumption } \\
\text { Cost } \\
\end{array}$ & $\begin{array}{c}\text { Taxes/Fixed } \\
\text { Costs } \\
\end{array}$ & $\begin{array}{l}\text { Total } \\
\text { Costs } \\
\end{array}$ & & \\
\hline Nov-01 & $\$ 122$ & $\$ 129$ & $\$ 27$ & $\$ 277$ & & \\
\hline Dec-01 & $\$ 243$ & $\$ 290$ & $\$ 34$ & $\$ 566$ & & \\
\hline Jan-02 & $\$ 308$ & $\$ 357$ & $\$ 37$ & $\$ 702$ & & \\
\hline Feb-02 & $\$ 300$ & $\$ 292$ & $\$ 35$ & $\$ 627$ & & \\
\hline Mar-02 & $\$ 300$ & $\$ 187$ & $\$ 33$ & $\$ 520$ & & \\
\hline Apr-02 & $\$ 235$ & $\$ 150$ & $\$ 30$ & $\$ 415$ & & \\
\hline May-02 & $\$ 204$ & $\$ 112$ & $\$ 29$ & $\$ 345$ & & \\
\hline Jun-02 & $\$ 105$ & $\$ 148$ & $\$ 29$ & $\$ 282$ & & \\
\hline Jul-02 & $\$ 146$ & $\$ 179$ & $\$ 32$ & $\$ 356$ & \multirow{3}{*}{$\begin{array}{c}\text { Running } \\
\text { Annual Total }\end{array}$} & \multirow{3}{*}{$\begin{array}{c}\text { Cost Intensity } \\
\$ / \mathbf{f t}^{2} \\
\left(\$ / \mathbf{m}^{2}\right)\end{array}$} \\
\hline Aug-02 & $\$ 138$ & $\$ 171$ & $\$ 31$ & $\$ 340$ & & \\
\hline Sep-02 & $\$ 122$ & $\$ 165$ & $\$ 31$ & $\$ 317$ & & \\
\hline Oct-02 & $\$ 138$ & $\$ 177$ & $\$ 32$ & $\$ 347$ & $\$ 5,094$ & 0.43 (4.6) \\
\hline Nov-02 & $\$ 162$ & $\$ 185$ & $\$ 33$ & $\$ 380$ & $\$ 5,197$ & $0.43(4.6)$ \\
\hline Dec-02 & $\$ 284$ & $\$ 187$ & $\$ 37$ & $\$ 508$ & $\$ 5,139$ & $0.44(4.7)$ \\
\hline Jan-03 & $\$ 243$ & $\$ 246$ & $\$ 38$ & $\$ 527$ & $\$ 4,964$ & $0.42(4.5)$ \\
\hline Feb-03 & $\$ 130$ & $\$ 160$ & $\$ 31$ & $\$ 320$ & $\$ 4,658$ & $0.40(4.3)$ \\
\hline Mar-03 & $\$ 154$ & $\$ 190$ & $\$ 35$ & $\$ 378$ & $\$ 4,516$ & $0.39(4.2)$ \\
\hline Apr-03 & $\$ 219$ & $\$ 124$ & $\$ 26$ & $\$ 368$ & $\$ 4,470$ & $0.38(4.1)$ \\
\hline May-03 & $\$ 113$ & $\$ 121$ & $\$ 25$ & $\$ 259$ & $\$ 4,383$ & $0.37(4.0)$ \\
\hline
\end{tabular}

\section{Simulated Whole-Building Performance}

The simulated energy use of the base-case model, as discussed in the Building Energy Simulation Methods section, using a measured weather file, is $241,706 \mathrm{kWh} / \mathrm{yr}$, at a site energy use intensity of $70.3 \mathrm{kBtu} / \mathrm{ft}^{2} \cdot \mathrm{yr}$ $\left(798 \mathrm{MJ} / \mathrm{m}^{2} \cdot \mathrm{yr}\right)$. The monthly energy use comparison between the base-case model and the Visitor Center is shown in Table 4. The annual site energy savings from November 2001 through October 2002 are 62\%, not including PV. The peak energy consumption has been shifted from the summer to the winter in an area where electrical peaks occur in the summer. Although not quantifiable, this reduces the impact on the utility grid.

The predesign energy cost savings goal was $70 \%$. Using a base-case model simulated with measured weather data from November 2001 through October 2002, the actual energy cost savings were 67\%. From November 2001 through October 2002, the measured energy cost intensity was $\$ 0.43 / \mathrm{ft}^{2}\left(\$ 4.63 / \mathrm{m}^{2}\right)$ or an annual cost of $\$ 5,094$, while the simulated base-case model was $\$ 1.30 / \mathrm{ft}^{2}\left(\$ 13.99 / \mathrm{m}^{2}\right)$ or an annual cost of $\$ 15,250$. The largest monthly cost savings occur during the summer months. The base-case, heat-pump cooling system uses significantly more energy with higher demand costs than the as-built cooltowers. The significant demand cost during the winter of 2001-2002 pointed to the importance of understanding what causes peak demands and whether the peak demand is controllable. This offers the most potential for optimizing energy costs. 
Table 4. Annual Visitor Center Energy Use Intensity (EUI) (end use numbers are for site energy use)

\begin{tabular}{|c|c|c|c|c|}
\hline Performance Metric & Units & Baseline Model & $\begin{array}{c}\text { Measured } \\
\text { Data }\end{array}$ & \% Savings \\
\hline Lighting & $\mathrm{kWh}$ & 107,781 & 28,957 & $73 \%$ \\
\hline Equipment & $\mathrm{kWh}$ & 26,769 & 26,769 & $0 \%$ \\
\hline Heating & $\mathrm{kWh}$ & 20,608 & 24,571 & $-19 \%$ \\
\hline Cooling & $\mathrm{kWh}$ & 63,915 & 4,401 & $93 \%$ \\
\hline Fans & $\mathrm{kWh}$ & 19,190 & 4,743 & $75 \%$ \\
\hline Domestic Hot Water & $\mathrm{kWh}$ & 3,443 & 3,443 & $0 \%$ \\
\hline \multirow{2}{*}{ Total Site EUI } & $\mathrm{kBtu} / \mathrm{ft}^{2} \cdot \mathrm{yr}$ & 70 & 27 & \multirow{2}{*}{$62 \%$} \\
\hline & $M J / m^{2} \cdot y r$ & 798 & 307 & \\
\hline \multirow{2}{*}{ Net Site EUI } & $\mathbf{k B t u} / \mathrm{ft}^{2} \cdot \mathbf{y r}$ & 70 & 25 & \multirow{2}{*}{$65 \%$} \\
\hline & $M J / m^{2} \cdot y r$ & 798 & 281 & \\
\hline \multirow{2}{*}{ Net Source EUI } & $\mathrm{kBtu} / \mathrm{ft}^{2} \cdot \mathrm{yr}$ & 227 & 80 & \multirow{2}{*}{$65 \%$} \\
\hline & $M J / m^{2} \cdot y r$ & 2,580 & 909 & \\
\hline Total Energy Cost & $\$ / \mathbf{f t}^{2} \cdot \mathbf{y r}$ & $\$ 1.30$ & $\$ 0.43$ & \multirow{2}{*}{$67 \%$} \\
\hline Intensity & $\$ / m^{2} \cdot y r$ & $\$ 14.0$ & $\$ 4.63$ & \\
\hline
\end{tabular}

The cooling savings are $59,514 \mathrm{kWh}$. The cooltower pumps consume $93 \%$ less energy than the base-case airsource heat pumps. The downdraft cooltower air delivery mechanism and radiant heating panels reduce fan consumption. Significant savings are realized from the daylighting and lighting systems. The annual lighting savings are 78,824 kWh. The heating system used more electricity than the base case because the efficiency of the electrical radiant system is $100 \%$; the base-case heat pumps were modeled with a COP of 3.0. When we implemented controls to reduce demand charges, average daily peak demand in winter declined by almost $50 \%$. Additional heating was required to compensate for the lighting systems, as these more efficient lights provide less heat than do the lights used in the base case. The increased heating energy use in the as-built Visitor Center that results from the electric heating systems and efficient lighting systems counteracts any energy savings from Trombe wall gains and the high-performance envelope. No equipment or domestic hot water (DHW) savings are expected because these loads depend on occupancy and installed capacity. The base-case loads represent as-built equipment power densities and operational schedules.

Source energy is the sum of the energy directly consumed at the site and the energy consumed by producing and delivering energy products. It represents the total energy required to deliver energy to a building. Documenting source energy consumption is useful when emissions from energy sources are of concern. We calculated the basecase source energy and measured source energy consumption based on 31\% electricity conversion and delivery efficiency from source to site. The electrical source-to-site efficiency was based on the conversion and distribution efficiency averaged over all sources of electricity generation in the nation, as specified by EIA's Annual Energy Review Outlook (EIA 2000). From November 2001 through October 2002, the measured net site energy consumption was $85,016 \mathrm{kWh}$, or $24.7 \mathrm{kBtu} / \mathrm{ft}^{2} \cdot \mathrm{yr}\left(281 \mathrm{MJ} / \mathrm{m}^{2} \cdot \mathrm{yr}\right)$. At $31 \%$ source-to-site electricity conversion efficiency, the source energy consumption intensity was calculated to be $80 \mathrm{kBtu} / \mathrm{ft}^{2} \cdot \mathrm{yr}\left(909 \mathrm{MJ} / \mathrm{m}^{2} \cdot \mathrm{yr}\right)$, which is a source energy consumption savings of $65 \%$ over the all-electric, base-case source energy consumption.

\section{Demand and Energy Cost Analysis}

The easiest method to reduce energy cost in a commercial building is to reduce the peak demand. The demand cost can contribute more than $50 \%$ of the total costs. An efficient building that uses very little energy could still have large demand charges with poor control. The evaluation team analyzed all the building loads and determined typical use trends to minimize the demand costs. Once the end uses that typically contributed to peak demands were identified, the researchers determined which loads might be shifted until a peak had passed.

The cost associated with demand can be found by multiplying the maximum power draw over a 15 -minute window by the $\$ 8.10 / \mathrm{kW}$ demand charge. The typical peak demand during the winter can exceed $44 \mathrm{~kW}$, when all end uses, including the hot water, lighting, and some heating, were on at the same time. Although the key contributor to the increase in peak demand was the turning on of lights in the morning, the heat was also on, partly because of the recovery from night setback. The hot water, lighting, and heating were at a maximum for the day during the demand peak. These types of loads offer the most potential for limiting the peak demand because they are not considered essential for short-term operation of the building. Hot water and heating systems can be 
temporarily turned off during potential periods of peak demand. During periods of low demand, the hot water and heating systems are turned on. The nighttime heating is used only if the building can be returned to a comfortable temperature without incurring a demand charge. This type of control strategy can also take advantage of on-site generation for potential demand reduction by offsetting the utility power draw with on-site generation.

We implemented the demand limiting controls at ZNP for the winter of 2002-2003 by continuously monitoring total power input to the building from the utility. Demand limiting is accomplished by continuously adjusting the heating set point of the Visitor Center based on the measured building demand. The BAS has the ability to reduce the temperature set point by $0.2^{\circ} \mathrm{F}\left(0.11^{\circ} \mathrm{C}\right)$ every 20 seconds when the demand is near the monthly peak demand. The maximum set point reduction is $10^{\circ} \mathrm{F}$.

The DHW units in the Visitor Center and Comfort Station have demand limiting controls. The DHW is disabled if the instantaneous building demand exceeds the weekly 10-minute peak demand. These units remain off for at least 8 minutes in an attempt to shift the load. If the building demand is less than the weekly peak demand, the DHW units are enabled. The DHW is mainly used for cleaning and is usually needed early in the morning. The hot water is not considered essential to the normal operation of the building. Before demand limiting, the cleaning crew emptied the water heater for cleaning, which caused a spike in the use early in the morning when the system tried to recover just as other loads were peaking. The strategy shifts the hot-water recovery to a more advantageous time based on the demand and rate structure.

Figure 7 shows the energy consumption of a heating day after demand responsive controls were implemented. Most noteworthy is that when the lights came on in the morning, the heating was reduced to maintain a flat profile. Heating consumption was decreased by $6 \mathrm{~kW}$ until daylighting reduced the electrical lighting loads and the PV system provided sufficient energy to limit demand. The heating energy consumption over the day is similar to a building without demand limiting because the load was shifted to a period when the heating system would not incur a peak demand. This load shifting strategy is an effective application of demand limiting because the building still used the same energy but over a longer period; the controls were effective because the peak was reduced significantly. In addition, the DHW load, which can peak at $3.3 \mathrm{~kW}$ in the morning, was also shifted to later in the day. The building may be underheated when the demand responsive controls reduce the heating set point. Zone temperature fluctuations were reduced during the load-shedding period by not setting back the nighttime set point, which allows for increased heat storage in the building thermal capacitance during periods of low demand. Again, the equipment and lighting loads could not be shifted or limited because they are necessary for building operation.

Figure 7. Demand limiting controls example, February 8, 2003

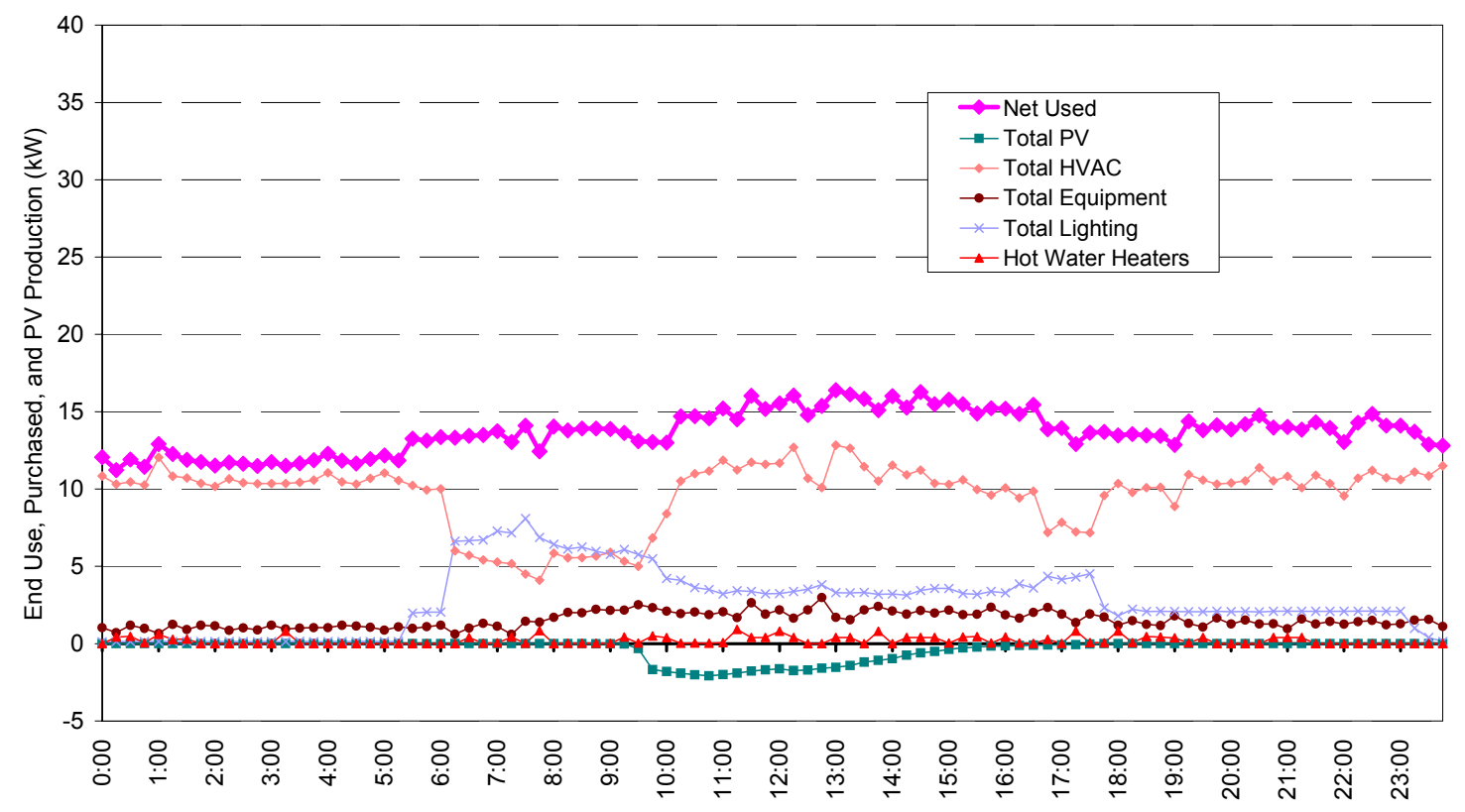

In general, by identifying short-term, nonessential end uses that contribute to peak demand charges, we developed a control strategy to shift these loads to significantly reduce demand charges. After overcoming some initial control implementation problems, we have been able to keep the peak demand under $30 \mathrm{~kW}$ for the entire year. Peak demands for previous heating seasons without demand limiting controls exceeded $44 \mathrm{~kW}$. 
Understanding the optimal demand controls involves studying precooling and preheating techniques to charge the thermal mass of the building during off-peak hours.

\section{Lighting and Daylighting Energy Savings}

A principal metric in the evaluation of the lighting and daylighting systems is their energy consumption. The total installed interior and exterior lighting was responsible for $31 \%$ of the total site load, and consumed $28,957 \mathrm{kWh}$, or $8.4 \mathrm{kBtu} / \mathrm{ft}^{2} \cdot \mathrm{yr}\left(95 \mathrm{MJ} / \mathrm{m}^{2} \cdot \mathrm{yr}\right)$. To quantify the success of Zion's lighting design coupled with daylighting, the evaluation team considered the conventional base-case building. The base-case model predicts the indoor and outdoor lighting end use consumption in a conventional non-daylit building according to 10 CFR 435 . This code outlines upper limits for LPDs by zone type for federal buildings. The base case predicted that a conventional retail and display building would consume $107,781 \mathrm{kWh}$ annually, or $31.4 \mathrm{kBtu} / \mathrm{ft}^{2} \cdot \mathrm{yr}\left(357 \mathrm{MJ} / \mathrm{m}^{2} \cdot \mathrm{yr}\right)$, of total indoor and display lighting electricity. Every attempt was made to schedule the lights in the base case to estimate what the lighting load would have been without daylighting and occupancy controls, and with typical manual control. Atypical occupancy and manual control can provide a source of error in comparing measured lighting consumption to the simulated base case.

The measured lighting loads, not including $400 \mathrm{~W}$ of parking lot lighting, were $75 \%$ less than a conventional building. These savings are attributed to improved lighting and daylighting design and operation, as ZNP incorporates a reduced LPD and daylighting design strategies with occupancy controls that are not included in the conventional base-case simulation. The total lighting savings and savings distribution are shown in Figure 8. Just by reducing the LPD from code requirement, Zion realized 50\% lighting energy savings. The installed LPD is lower than 10 CFR 435 recommends because the lighting design accounts for a daylighting contribution during the day, includes efficient fluorescent lamps and ballast, and places task lighting in the most advantageous spaces. Nighttime illuminance levels can be a concern when the installed LPD is lower than the recommended levels, as the daylighting contribution is not available.

A second type of lighting energy savings can be attributed to appropriate control of the installed luminaires. The Visitor Center and Comfort Station lighting control strategy involves multiple daylighting sensors combined with motion controlled switches. The authors expected that occupancy sensors combined with daylighting controls would displace $25,973 \mathrm{kWh}$ of electrical lighting and reduce lighting use by another $50 \%$.

Figure 8. Lighting and daylighting design savings for indoor lighting

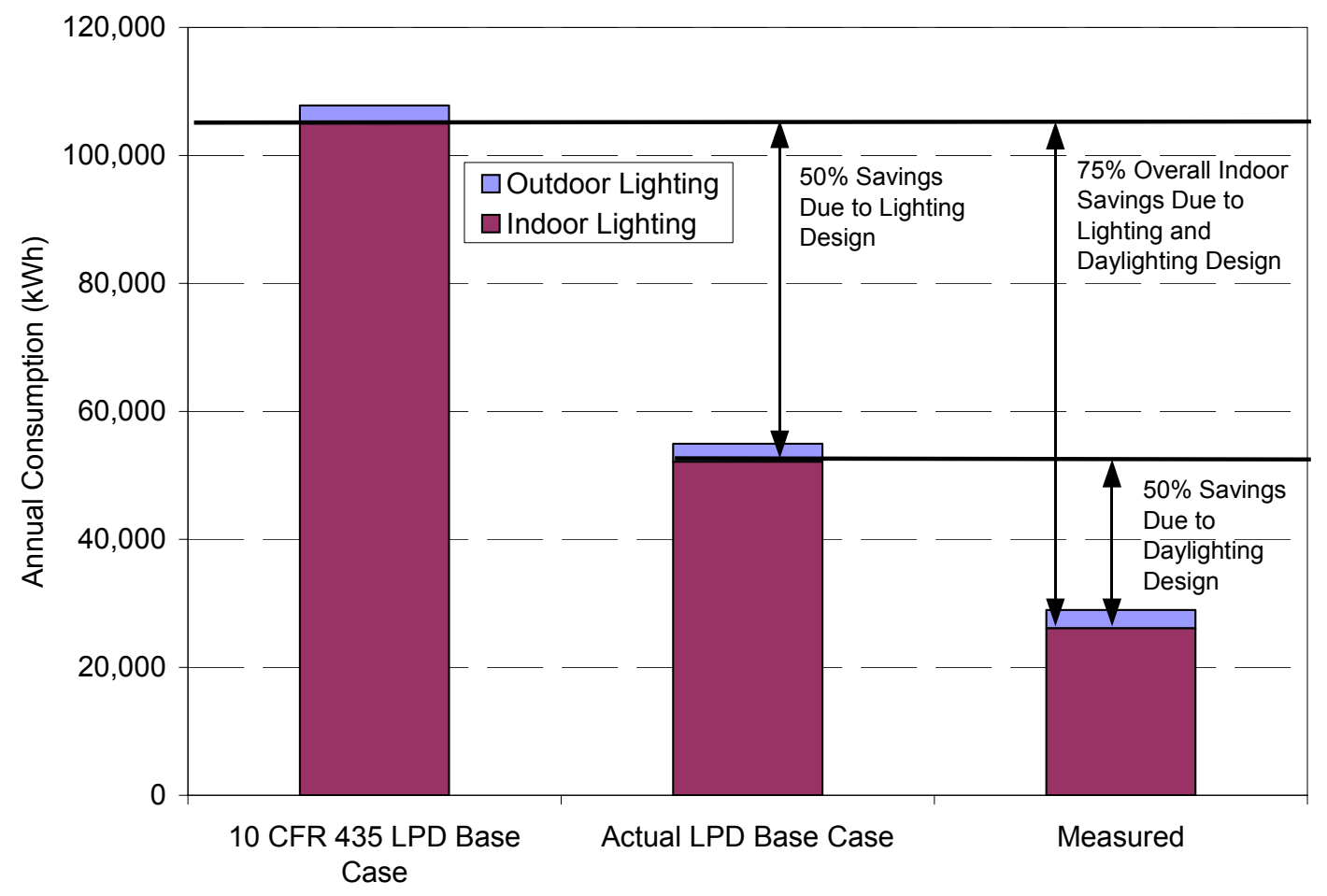


The original daylighting analysis for the proposed building intended to have many more lights completely off, with daylighting extensively reducing the electrical lighting load. Although daylighting has successfully reduced the lighting consumption compared to conventional buildings, the success of the daylighting at Zion has been restricted because of several issues in the building's design and implementation.

- The size of the specified clerestory visible glazing was not adequately communicated to the design team, which reduced the daylighting from the clerestories. The frames, mullions, screens, and automation mechanisms reduce the amount of visible glazing in the clerestory windows and were not considered in the original daylighting design. The visible window area must be specified when information is transferred from the energy consultant to the design team. The impact of screens must also be understood.

- The dark structural beams absorb and block significant amounts of the clerestory daylighting and uplighting throughout the buildings and were not considered when the daylighting features were designed. (Daylighting is more effective with white ceilings.)

- Stepped lighting controls work well if they are not in an area where detail work is being done. Continuous task lighting would offset the on/off sequencing of the lights and provide additional lighting at critical locations. The stepped daylighting controls have been problematic, as they resulted in uneven distribution and occupant complaints of on-off sequencing. The design of the stepped operation called for every other fixture to be on a separate circuit. Instead, every other row was installed on a separate circuit, which resulted in uneven distribution during stepped control operation. Continuously dimming fixtures would allow for even distribution of the electric lights, which would further reduce lighting consumption.

Continuous monitoring of the lighting and daylighting systems has enabled us to identify and address several problems. Clerestory glare problems were addressed with diffusing films, and adjustable blinds recommended for occasional glare in the offices. We added task lighting in critical areas, as the stepped controls, uplighting, and daylighting did not provide adequate illuminance levels for detailed work. Occupant-controlled task lighting must be placed and used correctly in daylit buildings with reduced LPD, especially for detailed task work.

\section{Heating System Evaluation Results}

The electric radiant system provides a large portion of the heat to the Visitor Center; however, the Trombe walls are also integral to the building's heating system. Temperatures at the interior surface of the Trombe walls can exceed $100^{\circ} \mathrm{F}\left(37.7^{\circ} \mathrm{C}\right)$ during the heating season. This warm surface provides radiant heating to the occupants. The result is that occupants with a view factor of the radiant surface should be comfortable at lower space temperatures. No attempt was made in this study to quantify the radiant effects of the wall on comfort. The NPS staff can control the temperature via the thermostats, so savings from radiant comfort would be connected with heating consumption.

The energy performance of the Trombe walls was monitored and analyzed over a two-year period. The analysis consisted of measured electrical end uses, Trombe wall temperature profiles, and thermographic pictures to determine the performance of these Trombe walls. Figure 9 shows the thermal distribution of the Zion Trombe walls at $8: 30$ p.m. on December 16,2000 . The interior surface temperature is generally uniform, at $90^{\circ}-96^{\circ} \mathrm{F}$ $\left(32^{\circ}-36^{\circ} \mathrm{C}\right)$. The wall temperature typically peaks between 8:00 p.m. and 9:00 p.m. The reduced wall temperature at the far right section of one Trombe wall is due to shading. The building shades part of the Trombe walls in the afternoons and reduces interior temperatures. The uneven temperature distribution in the middle of the interior wall is caused by the window mullions and other exterior wall shading. 
Figure 9. Interior infrared picture of Zion Trombe wall December 16, 8:30 p.m.

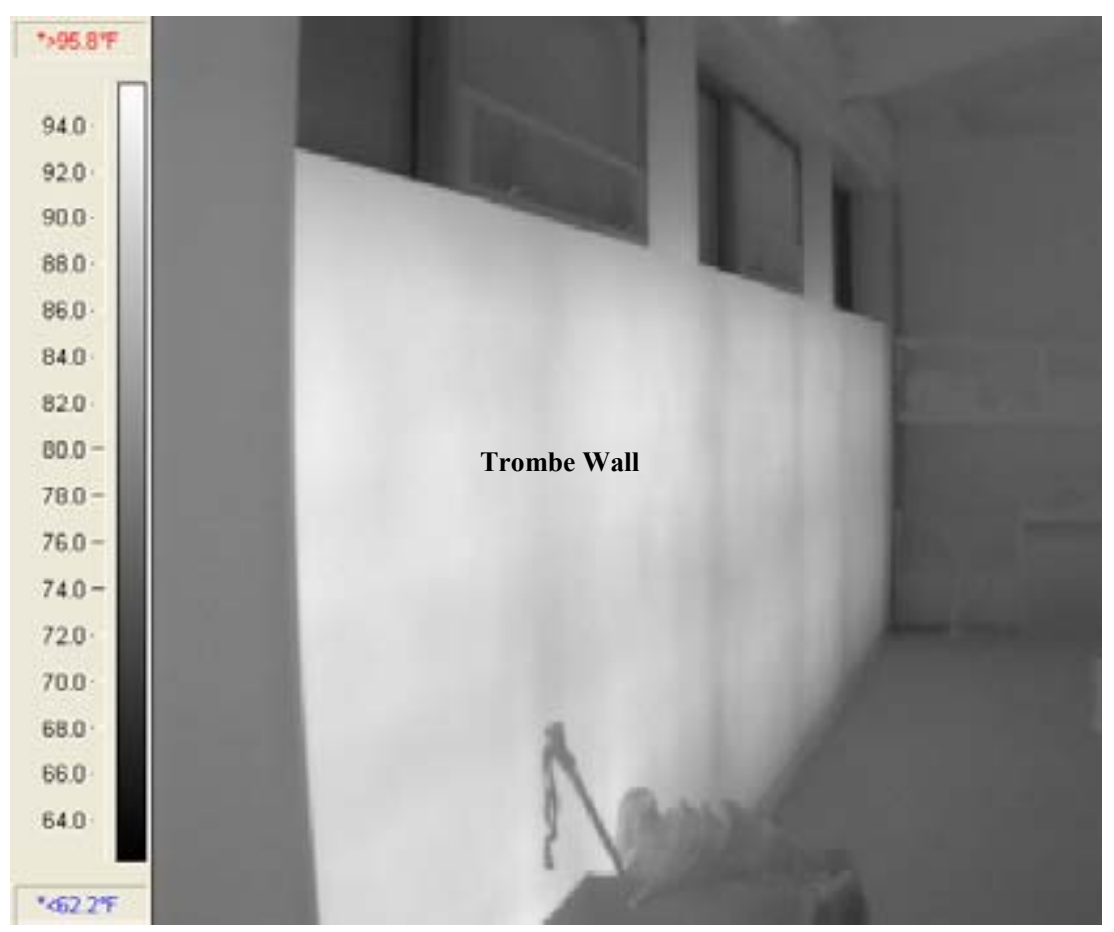

The temperature gradient through the wall was measured during the 2001-2002 heating season. With internal temperature measurements, the Trombe wall energy supplied to the building was calculated based on published heat flux calculation methods (Torcellini 2005). During the 2001-2002 heating season, the electric radiant heating system used $22,680 \mathrm{kWh}$ : the Trombe walls contributed $20 \%$ of the total heating. The Trombe walls imposed a heating load for only 2 of the 151 days of the 2001-2002 heating season. For the other 149 heating days, the wall was net positive. During the first 3 months of the 2002-2003 heating season, the total electrical heating energy used was $5,389 \mathrm{kWh}$; the Trombe walls provided approximately $41 \%$ of the energy or $3,800 \mathrm{kWh}$. This percentage was greater than the previous heating season of only $20 \%$ because the electrical heating system controls were improved and the weather was slightly warmer.

The heat added to the Visitor Center from the Trombe walls during cooling months is a concern, especially in the enclosed offices on the south side of the Visitor Center. Although the Trombes walls are shaded by overhangs, diffuse radiation incident to the exterior of the wall is transferred to the building. Because of the evaporative cooling system, this load is not generally seen by the building, although specific zones suffer from insufficient ventilation. We recommend that further research be completed to determine the summer Trombe wall loads and ways of reducing the impact. External shade cloths in the summer may help. In the initial design, the offices were on the north side and summer Trombe wall heat gain to the offices was not a concern. With the offices located directly next to the Trombe walls in the as-built design and separated from the cool air sources, these spaces can overheat. For buildings with conventional air-conditioning systems, careful Trombe wall design is essential so that summer gains are minimized. If buildings are flushed with evaporative cooling, the summertime cooling loads generated by the Trombe walls will not cause problems.

\section{Cooling Systems Evaluation Results}

The authors determined cooltower performance by evaluating energy use, water consumption, the ability of the natural ventilation, and the fans to cool the space. We calculated the energy consumed by water pumps in the cooltowers and circulation with the BAS based on a one-time power measurement and run time. Water consumption was determined by measuring the water flow to and from the cooltowers during operation. We measured the ability of the clerestory windows, cooltowers, and fans to cool the space by collecting indoor zone temperatures and through occupant feedback.

The cooltowers cool the building using only a small circulation pump. Circulation fans were added in August 2001 to help push cool air into the office areas. The total cooling energy (cooltower pumps and circulation fans) for 
the Visitor Center during 2001 was $4,940 \mathrm{kWh}$, or $7.5 \%$ of the total consumed energy, whereas for 2002, the total cooling energy consumed was $7,300 \mathrm{kWh}$, or $8.4 \%$ of the total consumed energy. (The differences between the numbers can be attributed to many variables, including the warmer summer during 2002.) The cooling energy intensity was $1.28 \mathrm{kBtu} / \mathrm{ft}^{2} \cdot \mathrm{yr}\left(14.5 \mathrm{MJ} / \mathrm{m}^{2} \cdot \mathrm{yr}\right)$, which was $77 \%$ less than a typical building in the western United States that uses $5.5 \mathrm{kBtu} / \mathrm{ft}^{2} \cdot \mathrm{yr}\left(62.5 \mathrm{MJ} / \mathrm{m}^{2} \cdot \mathrm{yr}\right)$ (EIA 2002).

The building uses control algorithms for precooling during nighttime periods under certain conditions. The controls check the high temperature for the current and previous days. If high temperatures exceed $90^{\circ} \mathrm{F}\left(32.2^{\circ} \mathrm{C}\right)$, the building will perform night cooling for the next day. The purpose of the night cooling is to remove any excess heat, such as Trombe wall heat, during the night while the temperatures are cooler. In addition, less energy is needed to cool the building because the internal loads are smaller. In some cases, the cost of energy is less during nighttime hours because of lower demands. The day following the night cooling period allows the building to "float" to the temperature set point instead of having to drop to the cooling set point.

The next metric in determining the cooling system performance was to evaluate the amount of water consumed in the evaporative cooling process. Water consumption is a concern because of the semidesert climate and the scarcity of water resources. The two cooltowers in the Visitor Center consumed 111,200 gallons (420,938 liters) of water during 2002. The water consumption was related to many variables such as temperature, relative humidity, and wind speed, with a loose correlation to the outdoor dry-bulb temperature. Flaws in the design of the cooltower plumbing caused unnecessary water use, which occurred when the sump pit overflowed during on/off cycling, which resulted in a $10 \%$ increase in water consumption.

Another measure of cooltower success and excess water consumption is the effectiveness of delivering the evaporative cooled air to the building. By design, the dry air enters the building and picks up moisture. However, some of the air may exit through the pads into the environment driven by evaporation on the exterior of the pads or cross-flow through the top of the tower, which results in more evaporation of water than would be expected with traditional evaporative technologies. The towers contained a simple internal diagonal blocking device to minimize this effect. The tower pads are not shaded from direct sunlight, which increases the evaporation rate and degrades the pads by UV exposure. Overall, the water consumption efficiency of the towers could be improved. Several recommendations regarding the cooltowers emerged from this analysis and are presented in the Conclusions section.

The natural ventilation and cooltowers have provided adequate cooling for the Visitor Center, with occasional periods of overheating and low flow rates. On several days the cooltowers could not meet the desired comfort range. This is typical of direct evaporative cooling. The system performed as well as a conventional direct evaporative cooling system. Such a system is effective only when the outdoor air is dry, which it is most of the time.

The thermal comfort range, as defined in ASHRAE Standard 55, is from $70^{\circ} \mathrm{F}\left(21.1^{\circ} \mathrm{C}\right)$ with $0 \%$ relative humidity to a maximum of $80^{\circ} \mathrm{F}\left(26.7^{\circ} \mathrm{C}\right)$ with $45 \%$ relative humidity (ASHRAE 2002). During 2001, the thermal comfort in the open areas was greater than the recommended temperature and humidity level for $3.7 \%$ of the occupied hours. During 2001, the temperatures in the enclosed offices were outside the comfort zone $36 \%$ of the occupied hours, which was unacceptable, and action was needed to correct the situation. Small circulation fans were placed in the adjacent space and a door louver was installed to allow air to freely enter the space. These small changes increased comfort in enclosed offices as the average temperature decreased, which was outside the comfort zone $20 \%$ of the time.

Interfacing the automatic windows in the building with the BAS was problematic. If the windows fail to open, the evaporative cooler has no relief and hence no airflow. The window operation technology was a weak point in the system. The windows must be open for air to flow. The actuators did not have feedback, so the state of the windows could not be determined. The problem was fixed by running an open/close cycle every night to make sure the windows are synchronized with the BAS.

\section{PV System Evaluation Results}

During the monitored year (November 2001-October 2002), the PV system produced a net 7,861 $\mathrm{kWh}$ (building normalized to $2.3 \mathrm{kBtu} / \mathrm{ft}^{2} \cdot \mathrm{yr}\left(26.1 \mathrm{MJ} / \mathrm{m}^{2} \cdot \mathrm{yr}\right)$, or $1,092 \mathrm{kWh} / \mathrm{kW}$ of installed capacity. The PV system offsets about $8 \%$ of the total annual energy load (approximately $15 \%$ during the spring and summer months and less than $5 \%$ of the load during the winter because of the higher electrical loads from heating and reduced PV production). The maximum PV production of $5.43 \mathrm{~kW}$ occurred in March during a cool period with good solar resources.

The PV system is a high-value feature even though it displaces only a small part of the total energy load. During daylit hours, the system can provide power for business operations without relying on power stored in the UPS system battery bank. This system handled 40 power outages that ranged from 1 second to 8 hours during the monitoring period. During February 2001 through May 2002, the building power was monitored to verify the 
operation of the UPS system. Because of the unreliable power in the area, the power shut off many times. A couple of times, the UPS system could not maintain clean power. If the grid shut down for less than 0.5 seconds, the scan rate on the BAS did not record the power failure. We believed that the panel had many split-second disturbances but could not record the instances. The total time the grid was unavailable and the UPS system was functional during the evaluation period was 107.4 hours or $2.6 \%$ of the time. The UPS maintained power to the building and the BAS during all but two of these instances.

\section{CONCLUSIONS AND RECOMMENDATIONS}

\section{Energy Performance}

The NPS staff, in conjunction with the authors, created a low-energy Visitor Center and used computer simulations to design the building envelope. The result was an integrated building system where the envelope contributes to the heating, cooling, and ventilation of the building. Overall, the ZNP Visitor Center uses $65 \%$ less source energy and has $67 \%$ lower energy costs than a typical building of the same size and operation. The innovative cooling solution effectively combines natural ventilation and direct evaporative cooling to reduce cooling requirements by $93 \%$. For the climate and scale of the Visitor Center, mechanical air systems can be replaced with localized heating systems to augment passive heating and cooling. Installing the PV and UPS systems added a substantial value to the building because of the poor power reliability.

\section{Integrated Design Process}

This section discusses recommendations developed from evaluating the process used to deliver low-energy commercial buildings. The recommendations are:

- Set energy performance goals and remain committed to achieving them throughout the design process. Creating buildings with low-energy architecture requires that clear, measurable energy performance goals be set and their progress tracked. Goals provide an energy saving target to achieve and a value to compare energy performance. For this project, an energy-cost saving goal of $70 \%$ (compared to minimum code) was adopted early in the design process (computer simulations showed that an energy saving goal of $80 \%$ was achievable). However, actual measured data indicated that the building energy cost saving was $67 \%$ because some construction and design changes were made before we could perform energy simulations to determine their energy impact. Nonetheless, setting a high energy saving goal enabled us to achieve significant savings.

- Use the architectural design and envelope of the building to save energy and enhance comfort. Form, shading, daylighting, materials, sizing, orientation, and specification of glass all have major impacts on building energy, lighting, and comfort performance. Use the mechanical system to make up for what cannot be accomplished by architecture and envelope alone, not to correct for a climatically ill-conceived architectural design. The total cost to construct the Visitor Center was less than the original program planned building. Integrating energy features into the envelope increased the total envelope cost; however, reducing infrastructure and mechanical systems (including elimination of the mechanical room) offset these costs.

- Apply a process that fosters a team approach to integrated design. The entire design team must be involved throughout the design process to reveal potential energy-saving opportunities and to get a whole-team decision. By involving the whole design team from the predesign stage, team members who ordinarily are not involved until later can identify ways to improve the design before the building is constructed. Followup evaluations showed that participants in the Visitor Center project agreed that the project benefited from this process. Specifically, integrating the energy analyst directly into the process to guide architectural decisions created a building that worked well with the energy decisions.

- Update energy models as design development progresses. There were important changes to the design and siting of the Visitor Center that occurred late in the design development stage. Changes to the orientation and location of offices reduced energy performance. For example, offices were located adjacent to the Trombe walls and far from the cooltowers, which led to comfort problems. Had each design change been re-analyzed with detailed simulations and updated zoning, the comfort problems would have been predicted and corrected (e.g., by adding back into design the cooltowers that had been removed or moving the offices). The simulations must be maintained from predesign through occupancy.

- Watch out for "Transparency Creep." Glass has a very strong impact on energy, comfort, and lighting performance. These impacts can be positive or negative, depending on many factors. Simulations allow us 
to optimize glass optical and thermal properties, sizing, orientation, placement, and shading. Glass is often added in an attempt to achieve transparency. The additional glass really does not provide transparency because of the strong exterior contrast from the sun. This building is overglazed on the north and west facades.

- Review the architectural program with concern for energy performance. Altering the architectural program to move interpretive displays to an outside patio reduced the size of the building, which resulted in enormous savings in first cost and overall energy use. Besides space area needs, establishing individual comfort ranges and allowing for interruptible hot water further improved the building's energy efficiency. Identifying areas where generally accepted design criteria may be replaced with creative energy saving solutions that meet or exceed the functional requirements of the building is beneficial.

\section{Lighting and Daylighting}

This section discusses recommendations related to the lighting and daylighting systems in the Visitor Center.

- Provide high reflectivity finishes to spaces that are daylit or have indirect light fixtures. Instead of the recommended white ceiling, a light-color pine, tongue-and-groove ceiling was installed in the Visitor Center. Designers intentionally chose the white ceiling to incorporate diffuse light in the space to reflect the lighting characteristics within the narrow slot canyon of ZNP, keep direct solar heat gain to a minimum, and make the interior psychologically cooler. The darker ceiling that was installed appears to have decreased the daylighting effectiveness in the space, which is compounded by the $88 \%$ uplighting fixtures.

- Account for window screens, attachments, and actual view area in daylighting analyses. Experience with the Visitor Center suggests significant reductions in daylight entering fenestration because of screens, reduced window view area due to mullion thickness, and shading deployed to reduce glare problems. The fenestration must be sized based on glass area during the design phase to include the impact of the frame and screens.

- Account for structural elements in daylighting analyses. Predictions related to daylighting during design development neglected the structural beams. The interior of the Visitor Center has several dark wood beams that contribute to the poorer-than-expected daylighting performance. Indirect lighting fixtures were installed level to the horizontal beams some distance below the ceiling. This also made the uplighting fixtures less efficient than intended.

- Provide lighting controls that dim in response to natural daylight. The lighting controls are stepped controls. The occupants tend to be distracted when the electric lights switch on or off. Dimming controls were added to minimize distractions. The dimming system can still be turned off.

- Provide task lighting to augment daylighting. The absence of task lighting further decreased the effectiveness of the daylighting system because occupants required more overhead lighting to maintain sufficient lighting levels in work areas. Task lighting was installed in these areas after the building was occupied, so building operators could decrease the ambient lighting threshold that controls the electric lighting. A similar problem existed in the Comfort Station where additional lighting was needed over the sinks. After occupancy, more lighting was provided over the sinks and the general lighting level could then be decreased. High priority areas should be identified during the design phase for possible task lighting or increased daylighting. Tubular daylighting devices could have provided necessary lighting over the sinks.

\section{Demand Responsive Controls}

This section presents recommendations developed from experiences implementing control strategies in the BAS that attempt to reduce the peak draw of electricity over a 15-minute period in any given billing cycle.

- Develop stable demand controllers and strategies. Demand controlling for the Visitor Center worked well in aggregate, but we found that isolated failure events lasting more than 15 minutes could instigate an excessive demand charge for that month. Software routines and hardware need to be reliable and default to appropriate settings after a system failure so that system resets are rare and not problematic. By the end of the monitoring period, the software was robust and provided good demand management. As with any system, improvements can still be made.

- Include forecasted weather data in demand responsive controls. Experience with the Visitor Center suggests that better performance is possible if forecasted and historic data were used in the demand control algorithms. Weather forecasts are readily available and can be used to make control decisions. 
- Re-evaluate thermostat setup and setback strategies. High thermal mass buildings such as the Visitor Center may show increased demand charges because of nighttime setback of the thermostats. Analysis should be performed to better understand the interactions between energy use and demand charges to determine optimal setback strategies.

- If PV is included in a project, use building energy simulation programs that model PV with demand interactions. Experience with Visitor Center called attention to the need to model demand controlling and interactions with PV generation. The lack of modeling prevents researchers from determining the full effectiveness of the current demand control strategies. Using a building simulation program that includes PV will allow for analysis on demand responsive controls and integrated cost analysis. Simulation programs must also be able to study demand-limiting controls.

\section{Trombe Walls and Heating System}

This section provides recommendations related to the Trombe walls along the south walls of the Visitor Center and Comfort Station related to the use of electric heat.

- Consider Trombe walls for passive heating of commercial buildings. Trombe walls were effective in providing a significant portion of the heating. It is clear that this building is heating-dominated. Passive solar heating is seldom used in commercial buildings because conventional wisdom dictates that such buildings need little heating. However, low-energy commercial buildings tend to require more heating because of reduced internal gains.

- Provide effective shading and active control for Trombe walls during the cooling season. The Trombe walls with their overhangs maximized heat gains in the winter. However, although reduced, the diffuse solar component still partially heats the wall in the summer. This problem was compounded by limited cooling capacities in the offices that were against the Trombe walls. Movable exterior shades are one possible means of mitigating unwanted heat during the cooling season, but it includes additional maintenance and operation. The walls should have been resized to better match the heating loads for these spaces.

- Consider electric radiant heating. An electric radiant heating system was used in the current project because it offered several advantages. The Visitor Center does not require a lot of heat and a ducted air system was not used for cooling. Therefore, adding a mechanical air system and the associated ductwork was considered too costly and complex for a small amount of heating. We arranged electric radiant heaters to direct heat at the locations where staff would spend the most time. Results show that occupants allowed lower thermostat temperature set points, probably because the radiant heating can provide comfort at lower dry-bulb temperatures. Electric radiant heaters also allow for a more cost-effective and precise temperature control because many thermal zones can be created. Although the electric heaters contribute to demand charges, they are simple to control. The cost of propane and transportation were key considerations in the creation of an all-electric building. The key is heating the building without incurring additional demand charges. This decision depends strongly on the metrics used to measure success. The solution was successful on a cost basis, but is less favorable on a source energy basis.

\section{Cooltowers and Natural Ventilation}

This section lists recommendations related to the cooltowers, which combine direct evaporative cooling with natural ventilation. The cooltowers cool the main area of the Visitor Center. Visitors find the towers fascinating and give them the type of attention often given to large fireplaces in public areas. The interaction of the visitors with the cooling system provides an amenity that normally would not be achieved with a traditional cooling system. This was not expected - that visitors would place value on the cooling system as an amenity for the building.

- Provide multiple opportunities for passive airflow. As a special class of passive natural ventilation, cooltowers require that interior partitions and fenestration be carefully designed to promote good circulation of cooled air. The enclosed offices tend to overheat because of insufficient airflow and continual heat gains from the Trombe walls. Exhaust fans originally installed in the office area were not sufficient to move air through these spaces to counteract the heat gains from Trombe walls. As with many passive systems, moving air mechanically should be avoided. The Trombe walls are shaded in the summer, but the diffuse component of the solar radiation still heats the wall. In the initial building design, the Trombe walls were to be adjacent to open spaces, not the enclosed offices. Late in the design process, the interior layout of the building was changed to place enclosed offices on the south side of the building 
adjacent to the Trombe walls. Even in the winter, the Trombe walls provide more heat than needed to the office spaces. As a result, circulation fans were installed between the public and private spaces to help induce additional air flow. These fans improved the comfort of the office spaces; however, they also increased the fan energy use and noise, which is to be avoided in passive cooling and heating.

- Use dampers on automatic controls rather than operable fenestration for natural ventilation. Operable windows are an important part of the natural ventilation system in the Visitor Center. Windows near the ground are operated manually; clerestory windows are on automated actuators. Experience showed that occupants do a poor job of operating the manual windows. In addition, the motorized window actuators are prone to failure and are difficult to interface with the BAS. Furthermore, the windows do not open much and the window screens reduce the effective opening. One suggestion is to separate the ventilation from the fenestration and use relief dampers for the passive ventilation, which would also increase the fenestration area and help with the daylighting. The control actuators would be typical HVAC controllers, reducing maintenance and integration issues.

- Provide solar shading of cooltower media. No shading was designed into the cooltowers to shade the media from direct exposure to sunlight. Although the consequences were not quantified, researchers suspect that solar shading would reduce water consumption. The shading also reduces UV degradation of the exterior media surface and the visible dissolved solids that accumulate on the exterior of the surface.

- Size sump pits to hold all the water in the system. To avoid wasting water, systems should be sized to avoid overflows. The Visitor Center cooltowers include a sump pit that was too small to hold all the intransit water. The installed sump pit has a 20 -gallon (76-liter) capacity. The trays and media, when wetted, hold about 20-30 gallons (76-114 liters) of water, which allows about 10-15 gallons (38-57 liters) of water to overflow the drain when the pump cycles off. This water is made up with fresh water when the pumps turn back on.

\section{Postoccupancy Research Methods}

This section discusses recommendations for researchers engaged in similar postoccupancy studies.

- Use dedicated self-contained data acquisition equipment to monitor energy performance. This study used the BAS to collect data on energy performance. This method was problematic and should be avoided. With current BAS and energy management systems, there appears to be a low probability of obtaining contiguous, error-free, measured datasets over a long period. A better solution is to use dedicated, selfcontained data acquisitions systems designed for unattended remote operation that do not use operating systems designed for personal computers.

- Provide researchers direct access to the BAS. In the Visitor Center project, researchers had access to and control of the BAS, which was helpful to understand and influence how the building was being controlled. Researchers were able to improve energy management strategies such as implementing and testing various demand responsive strategies. Access to the BAS allowed us to reduce the demand charges to the building and facilitated continuous commissioning activities. Another advantage of BAS access and control is having a full understanding of the various set points and control strategies to use as inputs into building energy simulation.

- Determine whole-building energy savings with as-built and base-case model comparisons. Ideally, the base-case site energy use, source energy use, and energy costs would be compared to an as-built model to calculate savings for a typical weather year. Energy savings uncertainties can be minimized when savings are determined from the comparison of one simulation to another simulation (e.g., base case to as-built). Because difficult-to-know inputs are held the same in both simulations, such comparisons remove much of the uncertainty inherent in an hourly building energy simulation. Variables that change throughout the year, such as inconsistent occupancy, set point changes, and equipment performance degradation, are difficult to account for in an annual building energy simulation. By comparing a base-case model to an asbuilt model with the same schedules, the uncertainty caused by these inconsistent variables is reduced. In the analysis of Zion, an as-built model of the Visitor Center and Comfort Station was beyond the scope of this analysis because of limitations in the whole-building simulation tools. These limitations include a lack of building integrated modeling techniques for the energy use and cooling capacity of cooltowers, difficulties modeling the as-built operation of subhourly demand limiting controls with integrated PV production, and uncertainties with Trombe wall thermal models. We attempted to account for the inherent 
uncertainty involved in comparing measured data to a simulation by calibrating the base-case model with measured weather data, measured equipment loads, and operation schedules.

\section{Summary of Conclusions}

Experience with the Visitor Center project, from early conceptual design through three years of postoccupancy monitoring, led to the following prominent conclusions. Although the design can be replicated by the NPS for future visitor centers, many of the conclusions are applicable to commercial buildings in general, especially retail operations. The Comfort Station is typical of many highway rest areas and state park facilities, and concepts from this design could be easily replicated across many future buildings in similar climates.

- A multiple-use commercial building that includes retail, office, and public assembly spaces, can be constructed with $67 \%$ energy cost savings over an equivalent, minimally code-compliant building.

- Buildings can be actively controlled to reduce electrical demand charges.

- For the climate and scale of the Visitor Center, mechanical air systems can be replaced with simple localized heating systems to augment passive heating and cooling to provide occupant thermal comfort.

- Cooltowers can effectively combine direct evaporative cooling and passive natural ventilation and deliver comfort comparable to mechanical direct evaporative cooling.

- Daylighting can augment electric lighting in retail spaces.

- Dark ceilings must be avoided to take full advantage of the daylighting and uplighting.

- Solar electric UPSs can add value to commercial buildings in areas with poor power reliability.

- A PV system can provide emergency power, offset peak loads, and reduce energy costs by reducing demand.

- Changes in rate structures can change the design decisions and operating strategies.

- Commercial buildings may shift from being cooling dominated to heating dominated because of lowenergy design.

The probability that a low-energy building will be achieved is improved by adopting the low-energy design process described in this paper. That process includes: (1) setting energy performance goals early on and remaining committed to achieving them, (2) assembling a diverse design team and involving them in all phases of the project, (3) applying computer simulation to predict energy performance at multiple stages of the design process, (4) using the architecture of the building to reduce energy needs and enhance comfort, and (5) evaluating delivered performance and continuously commissioning systems to improve performance. For Zion, we learned that the lowenergy design process enabled the building to achieve significant energy savings.

\section{ACKNOWLEDGMENTS}

This work was made possible under the U.S. Department of Energy's (DOE's) Office of Energy Efficiency and Renewable Energy. We appreciate the support and guidance of Dru Crawley, DOE Program Manager for HighPerformance Buildings as well as the following people who reviewed this document prior to publication: John Ryan at DOE; Michael McCabe at Navigant Consulting; Nadav Malin at BuildingGreen, Inc.; and Patrick Shea at the National Park Service. In addition, we would like to recognize those who helped collect information and provide analysis support for the effort including Stefan Craine, Kris Lasnik, and Michael Ketcham (NREL interns); Peter Ellis, Brent Griffith, Sheila Hayter, and Lauren Poole (NREL); Tom Wood (Montana State University); Joshua Bruce (former NREL employee), and Ed Hancock (Mountain Energy Partnership).

\section{REFERENCES}

ASHRAE 1989. ANSI/ASHRAE/IES Standard 90.1-1989. Atlanta, GA: American Society of Heating, Refrigerating and Air-Conditioning Engineers.

ASHRAE 2004. ANSI/ASHRAE/IES Standard 90.1-2004. Atlanta, GA: American Society of Heating, Refrigerating and Air-Conditioning Engineers.

ASHRAE 2002. ASHRAE Standard 55P, Thermal Environmental Conditions for Human Occupancy. Atlanta, GA: American Society of Heating, Refrigerating and Air-Conditioning Engineers.

DOE 1995. Code of Federal Regulations 10 - Energy. Washington, DC: Office of the Federal Register National Archives and Records Administration. 
EIA 2000. Annual Energy Outlook. U.S. Department of Energy. Washington, DC: Energy Information Agency. Pg. 217, Diagram 5.

EIA 2002. 1999 Commercial Buildings Energy Consumption Survey: Consumption and Expenditures Tables. Washington, DC: Energy Information Agency.

Hicks, T.W.; von Neida, B. 2000. "An Evaluation of America's First ENERGY STAR Buildings: The Class of 1999." ACEEE Summer Study on Energy Efficiency in Buildings Proceedings. Pacific Grove, CA. Pg 4.181, Table 1.

Pasqualetto, L.; Zmeureantu, R.; Fazio, P. 1997. “A Case Study of Validation of an Energy Analysis Program: MICRO-DOE-2.1E.” Building and Environment, Vol. 33, No. 1, June 1997. pp. $21-41$.

Torcellini, P.; Hayter, S.; Judkoff, R. 1999. "Low-Energy Building Design-The Process and a Case Study." ASHRAE Transactions, Vol. 105, Part 2. Atlanta, GA: American Society of Heating, Refrigerating and AirConditioning Engineers, Inc.; pp. 802-810; NREL Report No. 26144.

Torcellini, P.; Long, N.; Pless, S.; Judkoff, R. 2005. "Evaluation of the Low-Energy Design and Energy Performance of the Zion National Park Visitor Center." NREL Report No. TP-550-34607. Golden, CO: National Renewable Energy Laboratory, 156 pp. http://www.nrel.gov/docs/fy050sti/34607.pdf

Winkelmann, F.C.; Birdsall, B.E.; Buhl, W.F.; Ellington, K.L.; Erdem, A.E.; Hirsch, J.J.; Gates, S. 1993. DOE2 Supplement, Version 2.1E, LBL-34947. Springfield, VA: Lawrence Berkeley National Laboratory. National Technical Information Service. 


\section{REPORT DOCUMENTATION PAGE}

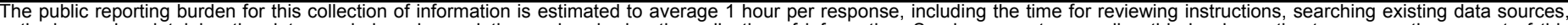

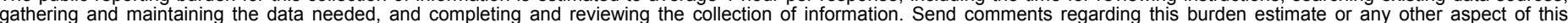

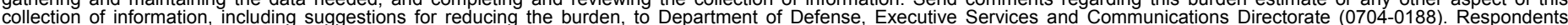

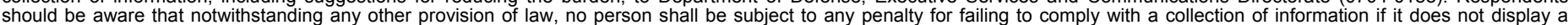

chuld be awaremat notwithstan

PLEASE DO NOT RETURN YOUR FORM TO THE ABOVE ORGANIZATION.
1. REPORT DATE (DD-MM-YYYY)
2. REPORT TYPE
October 2005
Conference paper
3. DATES COVERED (From - To)
2004-2005

4. TITLE AND SUBTITLE

Evaluation of the Low-Energy Design Process and Energy

Performance of the Zion National Park Visitor Center: Preprint

5a. CONTRACT NUMBER

DE-AC36-99-GO10337

5b. GRANT NUMBER

5c. PROGRAM ELEMENT NUMBER

6. AUTHOR(S)

N. Long, P. Torcellini, S. Pless, and R. Judkoff

5d. PROJECT NUMBER

NREL/CP-550-39013

5e. TASK NUMBER

BEC3.1001

5f. WORK UNIT NUMBER
7. PERFORMING ORGANIZATION NAME(S) AND ADDRESS(ES)

National Renewable Energy Laboratory

1617 Cole Blvd.

Golden, CO 80401-3393
8. PERFORMING ORGANIZATION REPORT NUMBER

NREL/CP-550-39013

9. SPONSORING/MONITORING AGENCY NAME(S) AND ADDRESS(ES)

10. SPONSOR/MONITOR'S ACRONYM(S) NREL

11. SPONSORING/MONITORING AGENCY REPORT NUMBER

12. DISTRIBUTION AVAILABILITY STATEMENT

National Technical Information Service

U.S. Department of Commerce

5285 Port Royal Road

Springfield, VA 22161

13. SUPPLEMENTARY NOTES

14. ABSTRACT (Maximum 200 Words)

Conference paper to be presented at the 2006 ASHRAE Winter Meeting in Chicago. Paper discusses NREL's role in the participation of the design process of the Zion National Park Visitor Center Complex and the results documented from monitoring the energy performance of the building for several years. Paper includes PV system and Trombe wall description and lessons learned in the design, construction, and commissioning of the building.

15. SUBJECT TERMS

Zion National Park; Visitor Center; low-energy design; building design; ASHRAE; energy performance evaluation; energy analysis and commercial buildings; high-performance buildings.

\begin{tabular}{|c|c|c|c|c|}
\hline \multicolumn{3}{|c|}{ 16. SECURITY CLASSIFICATION OF: } & \multirow{2}{*}{$\begin{array}{l}\text { 17. LIMITATION } \\
\text { OF ABSTRACT } \\
\text { UL }\end{array}$} & \multirow{2}{*}{$\begin{array}{ll}\text { 18. } & \text { NUMBER } \\
\text { OF PAGES }\end{array}$} \\
\hline $\begin{array}{l}\text { a. REPORT } \\
\text { Unclassified }\end{array}$ & $\begin{array}{l}\text { b. ABSTRACT } \\
\text { Unclassified }\end{array}$ & $\begin{array}{l}\text { c. THIS PAGE } \\
\text { Unclassified }\end{array}$ & & \\
\hline
\end{tabular}

9b. TELEPHONE NUMBER (Include area code) 